\title{
UNDERSTANDING NORMS AROUND THE GENDERED DIVISION OF LABOUR: RESULTS FROM FOCUS GROUP DISCUSSIONS IN ZIMBABWE
}

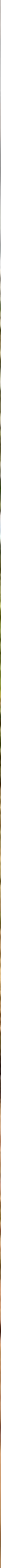




\section{CONTENTS}

OVERVIEW OF FINDINGS

INTRODUCTION

Research objective $\quad 5$

What are norms and why do they matter? $\quad 5$

Focus group discussions $\quad 6$

Sample composition

PART 1 - THE GENDERED DIVISION OF LABOUR AND THE 'STICKINESS' OF NORMS

Shared understandings shaping the gendered division of labour $\quad 8$

Beliefs underlying the distribution of work 12

'Economic norms' underlying productive and reproductive work 13

How skill is assigned 13

How value is assigned 14

\begin{tabular}{ll} 
Change over time & 14 \\
\hline
\end{tabular}

\begin{tabular}{ll} 
Long-lasting change & 15 \\
\hline
\end{tabular}

Temporary or seasonal change 17

PART 2 - EVIDENCE OF APPETITE FOR CHANGE $\quad 18$

Consequences of the division of UCDW 18

\begin{tabular}{ll} 
Desire for change & 18 \\
\hline
\end{tabular}

Looking to the future $\quad 19$

PART 3 - STEPS TO INFLUENCE CHANGE

Compelling ways of sharing messages $\quad 20$

Who people listen to and follow 20

Trusted sources of information 20

Supporting change

Implications

CONCLUSIONS

ANNEX 1 - FOCUS GROUP SCRIPT Please see here
ANNEX 2 - PROFILES OF THE FGD DISTRICTS

ANNEX 3 - INFORMATION ABOUT FOCUS GROUP PARTICIPANTS

ANNEX 4 - RANKINGS USED IN THE EXERCISE ON 'ECONOMIC NORMS’

ANNEX 5 - TASKS RANKED BY PERCEIVED ACCEPTABILITY FOR MEN AND FOR WOMEN IN SELECTED FGDS

ANNEX 6 - FULL LIST OF SAYINGS THAT EMERGED AROUND THE DIVISION OF WORK

ANNEX 7 - REFLECTIONS ON THE METHODOLOGY

Feedback on the focus groups from facilitators and participants

Additional comments

REFERENCES 


\section{OVERVIEW OF FINDINGS}

Oxfam's Women's Economic Empowerment and Care IWECarel programme recognizes that the 'heavy' and 'unequal' responsibility for providing unpaid care and domestic work (UCDW) limits women's choices and their ability to engage in other aspects of life, such as education, livelihoods, politics and leisure. International institutions have increasingly recognized the significance of UCDW to human and economic development, and the importance of care provision in overcoming poverty and inequality. Over the past five years, WE-Care research has underlined the extent to which such work is invisible to men and women, and to government authorities: it is widely held to be of little value and importance, and to require few skills. Accordingly, WE-Care programmatic activity seeks to reduce and to redistribute responsibility for care and domestic work - between women and men, and between poor families, their employers and the state. This emphasis is finding broader resonance, notably within the deliberations of the international community. Goal 5.4 of the Sustainable Development Goals, adopted in 2015, focuses explicitly on recognizing and valuing UCDW.

'Norms' refer to the shared expectations held by a given community; these are often held in place by social approval or rewards for conformity and by disapproval or sanctions for transgressions. Understanding how and why such norms hold sway can provide a powerful means for understanding the gendered division of work that prevails in many communities and inform strategies aimed at promoting change.

WE-Care activity to date has affirmed that social norms are powerful drivers of the current (unequal) patterns of providing care. This understanding is also supported by a growing body of academic work which has sought to interrogate gendered social norms and their purchase across contexts, and to seek to shift those norms which result in harmful practices. According to Mackie et al. (2005), if a 'harmful practice is social in nature', programmes 'may be more effective if they support the revision of social expectations of people throughout the entire community of interest', rather than focusing on individuals.

This report draws on research that has sought to develop a methodology to understand norms underpinning UCDW and associated behaviours in a given context, to observe where some norms might be undergoing a process of change, and to identify compelling ways to communicate about such change. The aim of the research is to inform WE-Care programming and create more effective local activities, public communications and policy proposals that might address the inequitable distribution of UCDW.

In particular, this report analyses discussions that took place across six focus groups in four communities in rural Zimbabwe in 2017. The report is organized into three parts. The first part describes shared understandings underlying the gendered division of work, factors explaining how and why they are so firmly held, and limited change over time. The second describes evidence pointing to some desire for a more equitable distribution of work. The third outlines participant perspectives on how messages could be communicated effectively and what other steps could be taken to advance processes of change.

Analysis of the discussions affirmed the following shared understandings, to which participants referred when explaining how work is distributed within communities. On this basis, we can infer gendered social norms that shape male and female activity in productive and reproductive work.

- Women should have overall responsibility for UCDW and, where possible, should also participate in productive or income-generating activity.

In 'typical' families within the focus group communities, participants reported that women were responsible for all household chores. This expectation that was often expressed in terms of 'respectability' and hard work featured strongly in a variety of sayings that participants identified to explain the qualities of 'good women'; for example, Mukadzi chaiye haazorori: A respectable woman does not rest, she is always working, which was identified as the most resonant saying in one of the focus groups. Care work was linked both to women's identity and self-worth - the kitchen in particular was described as an area in which women had control - as well as to how they were perceived as wives, mothers and members of their communities. In addition to household work, in most cases, women farmed alongside their husbands and took part in other income-generating activity; however, they felt that this work was often not recognized.

- Children, especially girls, should participate actively in UCDW.

Girls took on the lion's share of household tasks assigned to children. Participant comments highlighted the importance of early modelled behaviour - girls, for example, were said to be 'always with their mothers' and therefore to adopt the same responsibilities. The discussions around the activities that children and young people were carrying out suggests that norms around age as well as gender were influential in shaping the distribution of tasks within households.

\section{- Men should be responsible for engaging in productive and income-generating activity to provide for their family's needs.}

The role of 'busy' and 'organized' men as family breadwinners also received considerable emphasis - as attested to in another common saying that emerged in the discussions: Mukadzi kana murume chaiye chaiye anochengeta mhuri yake: A good man will provide for his family's needs.

- It is unacceptable for men to engage in most types of UCDW.

Overall, participants felt that very few members of their community would respond positively to male involvement in UCDW, and that most would shun such households. The discussions also attested to a range of sanctions in place 
where such expectations were violated. However, while this general tendency was evident in the discussions, there was also considerable nuance. First, respondents identified that certain tasks relating to the direct care of people were particularly degrading to men and undermined their manliness - e.g. changing nappies or bathing children. Tasks perceived as requiring more strength and potentially involving the use of equipment (such as fetching water or fuel using a cart) were more acceptable, as were those which were less visible. Second, involvement in care work not only had implications for how such men themselves were perceived (as weak, foolish or useless) but also for how their relationships with their wives were viewed - the supernatural was invoked in perceptions that wives had used 'witchcraft' or a 'love potion'. Third, the perceived acceptability of male involvement in care was also dictated by the situation of his wife. It was perceived as unacceptable if she was present and able, but more acceptable if she was ill, had recently given birth, or was engaged in productive work outside the home. Finally, acceptability appeared to hinge in large part on whether men were also fulfilling their role as provider - to the extent that this was true, their involvement in unpaid care was viewed relatively more positively, and they were perceived as 'family men', whereas if they did not have other productive work they were perceived as 'lazy' and 'incompetent'. These types of variations point to a range of possible entry points in terms of designing strategies and activities aimed at bringing about change.

- It is more acceptable for women to engage in productive or income-generating activities that are 'not too heavy' and that accommodate child-raising and domestic activity.

In several of the conversations, participants expressed that women should be involved in 'light' activities whereas men should undertake 'heavier' chores - although this perception was at odds with the physical demands of many activities that women actually were taking on such as fetching water and fuelwood. Paid work that women could do at home while also conducting UCDW, was also perceived as desirable.

- It is unacceptable for a woman to forego her unpaid care and domestic responsibilities, even if the household is able to pay for these services to be provided.

Women who did not participate in UCDW, even if they were engaged in other productive work, were described as 'lazy' and 'wayward'. A lack of involvement in household chores would threaten marriageability and could potentially give rise to divorce. There was agreement that the community would criticize and condemn such women, and that girls might be subject to the threat of violence. This censure of women held true even if their households were in a position to pay for help with undertaking UCDW.

Norms relating to gender (as well as age) were reflected in discussions around the typical division of labour within households in the selected communities, and also in the resonant sayings and sanctions that reinforced expected behaviours and penalized any transgressions. The division of labour was justified with reference to biology and culture - reinforced by perceptions that 'female' activities required fewer skills and were less valuable than those primarily undertaken by males, though childcare was considered valuable. Participants assigned skill to activities primarily based on the perceived need for formal schooling or training, while value was assigned primarily on the perceived contribution of an activity to survival needs. Norms around the gendered division of work appeared to be loosening slightly, but this process has been outpaced by changes in behaviour induced by economic hardships - namely growing female involvement in paid work and some instances of male engagement in UCDW.

The discussions also uncovered information that could inform processes of change. Many female participants recognized adverse consequences of the gendered division of labour, citing particularly concerns over health, and women and younger men tended to argue for a more equitable division of UCDW. Across the focus group discussions (FGDs), participants favoured a more equitable division of work among the young people in their communities, once they formed families of their own.

\section{Participants also reflected on trusted messengers in their} communities and ways of communicating messages, though role models (men taking on care roles) were in relatively short supply. They also discussed concrete steps to encourage an alternative division of UCDW among the younger generation. They agreed that to achieve this, parents should treat sons and daughters equally and divide chores among them without regard to gender; males would need support including training from an early age to carry out UCDW, and a platform for identifying like-minded men and facilitating interaction among them. For women, some changes in mindset regarding male involvement in UCDW might be needed, so they would not view such activities as demeaning and constituting an invasion of their space.

Finally, the report outlines some preliminary implications of this research. It suggests that the most malleable norms may be those being directly challenged by the country's economic crisis and the behavioural changes it has prompted. It outlines several potential objectives of future activity, including a reframing of the traditional roles assigned to women and to men; challenging women's perceptions of male involvement in care, as well as community perceptions of what constitutes light and heavy work, and skills and value; highlighting positive aspects of shared care work and adverse effects of the existing care workload for women; and emphasizing existing male involvement in care and seeking to extend this into new areas. A number of specific activities are proposed. 


\section{INTRODUCTION}

\section{Research objective}

For several years, Oxfam GB has made increased efforts to address heavy and unequal care work and to raise the profile of care as a cross-cutting development issue. This involves supporting local organizations and women's groups to increase public recognition of care work, advocating for investments to reduce the unnecessary drudgery of care, and redistributing care responsibilities more equitably. Building on these efforts, the WE-Care initiative started in 2013, aiming to produce new methodologies and context-specific evidence about care work to influence the design of development initiatives and policy. Its ultimate objective is to secure a reduction of arduous domestic tasks and the redistribution of responsibility for care and domestic work - between women and men, and between poor families, their employers and the state.

Research by WE-Care has found that the extent and significance of UCDW is not visible to men and women in families, nor to government authorities. Care work is perceived to be of low value and little importance, and to require few skills. The need to revisit this perception is gathering greater traction more broadly. This is evident in the international community's adoption of the Sustainable Development Goals, where Goal 5.4 seeks to 'recognize and value unpaid care and domestic work through the provision of public services, infrastructure and social protection policies, and the promotion of shared responsibility within the household and the family as nationally appropriate'.?

WE-Care programmes have understood that social norms are powerful drivers of the current (unequal) patterns of providing care. This understanding is also supported by a growing body of academic work which has sought to interrogate gendered social norms and their hold across contexts, and to seek to shift those norms which result in harmful practices.

The purpose of the current research was to develop a methodology to understand the social norms that shape care-related behaviours, to identify where gendered norms are shifting, and to identify compelling ways to communicate about change. This information is intended to inform WE-Care programming in order to create more effective local activities, public communications and policy proposals related to social norms around UCDW.

This report seeks to synthesize the findings of six FGDs conducted in four districts of Zimbabwe. Building on earlier Rapid Care Analyses (RCAs) and other Oxfam activities under the WE-Care programme, these discussions sought to understand the gendered social norms underlying the persistent highly gendered division of labour in these communities to inform Oxfam programming, to raise awareness among communities around the challenges of UCDW, and to create a more accurate tool for use in future FGD exercises. Finally, this report aims to recognize and galvanize women's and men's groups that are taking forward important influencing work on UCDW on the ground.
What are norms and why do they matter?

The Align platform provides a useful definition of norms: 'the often implicit, informal rules that most people accept and abide by. They are influenced by belief systems, perceptions of what others expect and do, and sometimes by perceived rewards and sanctions. Norms are embedded in formal and informal institutions and produced and reproduced through social interaction. They change when sufficient people choose or are compelled to act in a different way and a new norm is established. ${ }^{3}$ As this definition attests, norms cannot be inferred directly from what people in a community do land do not dol. Rather, their prescriptive quality requires a deeper understanding of reference groups, underlying motivations and beliefs (how people explain and justify patterns of behaviour) and the penalties communities impose on members who deviate from accepted behaviours. ${ }^{4}$

By focusing on how community beliefs and actions condition outcomes beyond those of individuals, ${ }^{5}$ the study of norms has made a crucial contribution to our understanding of how inequitable practices and outcomes are established and maintained, and correspondingly, how to influence processes of change. ${ }^{6}$ If a 'harmful practice is social in nature',

programmes focused on changing behaviours at the individual level are unlikely to be successful; programmes 'may be more effective if they support the revision of social expectations of people throughout the entire community of interest' . According to Heise (2013), through a better understanding of which norms are shaping outcomes and how, it is possible to 'suggest how important a norms-based component may be as part of an overall change strategy'. ${ }^{8}$

Researchers have found that social norms are useful in understanding the persistent inequitable division of UCDW in most societies. Studies have shown that this division persists, in part owing to norms which prescribe the roles and behaviours considered to be appropriate for males and for females within a given society, and the acceptable sanctions if these roles are transgressed. Norms can be changed - this is the explicit intention of several interventions focused on UCDW $^{9}$ - though this is not without the risk of backlash, which can range from ridicule and scorn to physical violence against those who are seen to be deviating from social norms. ${ }^{10}$

A focus on shifting norms around care is a fundamental premise underlying the WE-Care initiative. It its view, 'lasting change' requires 'a shift in social norms so that care work is not seen as "women's work" but as everyone's responsibility. This leads to a redistribution of care tasks from women and girls to men and boys, and creates new, positive norms that encourage men to care for their families and children... We also need to change norms which undervalue care, so that care work is understood as being critical to social and economic development. Attitudes need to change at every level - from individual to community to government - to ensure that care work is recognized, equally distributed, and invested in'.11 
While redistribution from women to men is a fundamental component, so too is the shifting of some of the responsibility and costs of care provision to the state and the private sector.

In what follows, we aim to identify and explain the social norms that appear to be shaping the behaviours of women and men in the communities where the FGDs were conducted. We rely on discussions in which all-female and mixed-sex groups gave their insights into the gendered patterns of UCDW in their communities, the beliefs underpinning these patterns and ways in which they are enforced, desire for and experiences of change, and compelling ways of communicating about change.

\section{Focus group discussions}

This exercise builds upon Oxfam's previous RCAs and experiences in the WE-Care programme. The RCAs involved FGDs that sought to enable practitioners to understand care work in particular contexts and 'find practical solutions to problematic tasks and patterns of care', 12 by exploring: care relationships; patterns of time use; factors prompting changes in unpaid care - including external shocks and social norms around care; the most problematic care tasks; and priority options moving forward. ${ }^{13}$ The present exercise involved FGDs that aimed to explore social norms around care in greater depth, given that in the RCAs these appeared to be an important underlying influence and potential lever for change. The FGD was structured to incorporate RCA results and to invite participants to reflect on what they suggested about gendered norms within their communities (see Annex 1 for the focus group script, and Annex 7 for feedback and reflections on the methodology).
In August 2017, Oxfam and partners Bekezela, Association of Women's Clubs (AWC) and Kunzwana conducted the FGDs in six wards in four districts of Zimbabwe (for details, see Annex 2, also Figure 1). The wards were selected in part because they are sites where WE-Care activities had been implemented, and because they had been recommended for approval to the local Rural District Council by the Social Services sub-committee, a normal administrative procedure for development projects. They are:

- Bubi district, Ward 11 and Ward 15 [hereafter, B11 and B15]

- Gutu district, Ward 9 [K9]

- Masvingo rural district, Ward 20 and Ward 24 [K20, K24]

- Seke district, Ward 10 [01]

The four districts are overwhelmingly rural lbetween $96 \%$ and $98 \%$ ) with relatively high net primary school attendance $185 \%$ to $90 \%$ ) and lower net secondary school attendance (from $36 \%$ in Bubi district to $58 \%$ in Seke district). Access to sanitation and to electricity is generally lower and more variable across the districts, with sanitation access ranging from $21 \%$ (Bubi) to $52 \%$ (Gutu), and electricity access from $9 \%$ (Gutu) to $35 \%$ (Seke). A higher share of people can access cooking fuel and clean water - for fuel, between $80 \%$ (Seke) and $94 \%$ (Gutu), and for water, between $58 \%$ (Masvingo) and $78 \%$ (Bubi). The districts are reliant on farming, which forms the chief activity of the focus group participants, and in Bubi district, gold mining, though this is reported to have had very detrimental effects on health and the environment. ${ }^{14}$ The overall context of widespread unemployment and underemployment, and resulting hardship, is evident in the discussions.

\section{FIGURE 1 MAP OF DISTRICTS OF ZIMBABWE}




\section{Sample composition}

A brief review of the composition of the focus groups is useful in three respects. First, it gives insights into the profiles of participants in the discussions. Second, although the aim is not to be representative, comparing the characteristics of FGD participants to those of the general population can give some insights into whose views they are likely to represent land if any groups are likely to be excluded). Third, the analysis can also point to groups for which additional recruitment efforts may be needed for similar exercises in the future.

Participants were selected from those individuals who had participated in at least one WE-Care activity and using random selection. Overall, 69 people participated in six focus groups, with demographic data available for 68 participants (see Table Al in Annex 3).

Three of the focus groups were female-only and three were mixed-sex. Overall $77 \%$ of participants were female; in the three mixed-sex focus groups, the share was 59\%. Participants' ages ranged from 18 to 70 years; across the groups, the median age ranged from 42 to 56 - with relatively few people at the lower and upper ends of the distribution. Five participants ( $7 \%$ of the total) were aged 30 or under (three women, two men) while 13 participants (19\%) were aged 60 or over (nine women, four men). The median age of the population in Zimbabwe is 19 years, and current life expectancy is 60 years (World Development Indicators, 2017), suggesting that our sample is skewed towards older people.

The lack of any male-only groups should be highlighted, given that the perspectives of men are likely to be particularly valuable in understanding better the persistence of unequal caring responsibilities. It is attributed largely to the very limited number of young men (aged 18-35 years) in Bubi and Masvingo districts given that, owing to economic hardship, many have migrated to seek opportunities for gold panning/artisanal mining in other parts of the country, or to work in Botswana or South Africa. The FGDs were held off-season, i.e. during the dry season (chirimo/ebusika), so farming responsibilities are likely to have posed less of a constraint than would otherwise have been the case.

Most participants in our sample were married - over $60 \%$ while around $15 \%$ each were widowed or divorced, and $9 \%$ had never married. The majority (56\%) reported having attended 'some secondary school' while $40 \%$ reported a primary education only; two participants reported having had no education and one had completed high school. The size of participants' households ranged from two to thirteen members, with the median size between four and six.

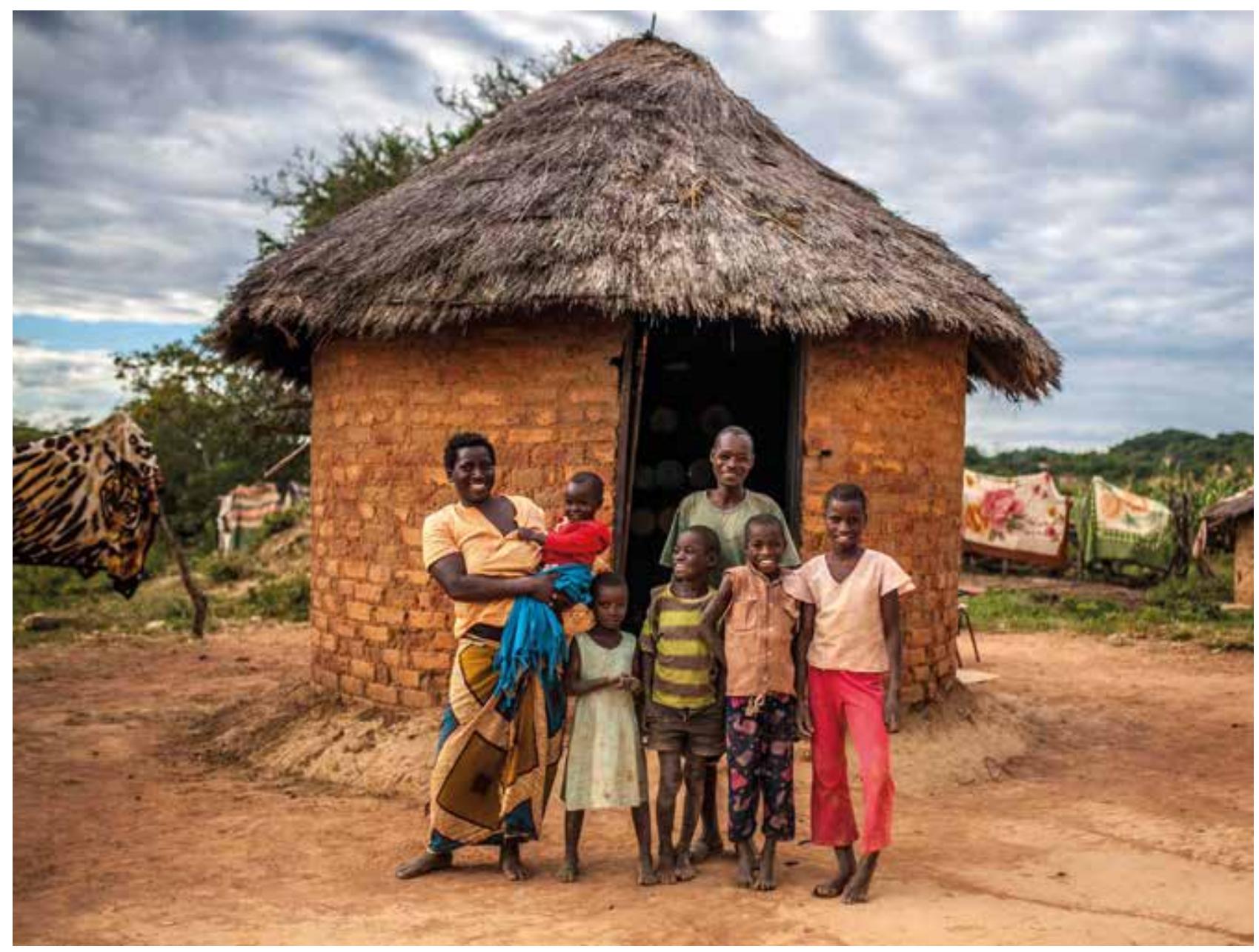




\section{PART 1 - THE GENDERED DIVISION OF LABOUR AND THE 'STICKINESS' OF NORMS}

Part 1 of this report focuses on the shared understandings shaping the gendered division of work within households in the selected communities, the sanctions that reinforce expected behaviour and penalize transgressions, and how these are reflected in resonant sayings. It explores the beliefs used to explain and justify these understandings, and their reflection in perceptions that most 'female' activities required fewer skills and were less valuable than 'male' activities. Finally, it describes perspectives on change over time; the evidence suggests that there has been some shift in underlying norms, but that these have been outpaced by changes in gender roles induced by economic hardship.

\section{Shared understandings shaping the gendered division of labour}

\section{- Women should have overall responsibility for UCDW and, where possible, should also participate in productive or income-generating activity.}

FGD participants described a highly gendered division of labour in 'typical' families within their communities, in which women were responsible for all household chores [all wards]. In one all-female discussion, participants estimated that approximately two in ten men in their ward took part in UCDW [K9]. Daughters-in-law were singled out as having the most household responsibilities [B15].

'All household activities are the job of the mother.' [Female, 39, K24]

'Mothers are the ones who have the responsibility of doing household chores as children will be at school, hence there will be no one to assist them.' [Female, 44, K9]

'A daughter-in-law is actually the one who is supposed to do all the household chores. Others might do them here and there, but it will not be their mandate to do those chores.' [Female, 54, B15]

'Men cannot be seen carrying buckets of water or sacks of maize going to the well or grinding mill when a woman is there, because what makes a home is the woman.' [Female, 44, K9]

The role ascribed to women is also reflected in several sayings and proverbs that participants identified as having resonance within their communities, which focused on respectability and hard work (for a complete list of sayings around the division of work, see Annex 6).

Mukadzi chaiye haazorori: A respectable woman does not rest, she is always working [01, identified as most resonant saying]

Mukadzi chaiye haasiye murume wake achiita basa repamba: A respectable woman does not allow her spouse to do care and domestic work [01]

Mukadzi chaiye chaiye anoshanda mabasa ese epamba: A respectable and good woman does care and domestic work and any other task around the homestead [01]

Mukadzi chaiye chaiye anoona kuti mhuri yake yakachengetedzeka - kubva kuna baba nevana: A good woman ensures that her whole family from children to the spouse are well looked after and are secure [01]

Umama oqotho ubonakala ngokwenza imisebenzi yangekhaya: For one to be called a good woman, she should be hard-working and do all the care and domestic work [B11]

Mushamukadzi: A respectable household is underpinned by a woman [K24] 
Participants observed that women as well as men perpetuate some sayings that reinforce gendered norms and may discourage male involvement in household activities such as cooking. In one FGD, participants commented that women aged over 45 referred to the kitchen as their domain and chase their husbands out, and that men's over-involvement in 'their kitchens' makes them feel insignificant as women. Domestic work is therefore a key enabler in their maintaining their identity as women [01].

In addition to doing housework, in most cases women farmed alongside their husbands and took part in other incomegenerating activities 'such as doing menial jobs (maricho) to generate school fees for the children' [K9].

In two all-female focus groups, participants reported that while women's engagement in farming and other income-generating activities added further to their workloads, this was often not acknowledged within their households and communities.
'Even in cases where a woman becomes the breadwinner, she should not tell her neighbours or other people she interacts with that she has an incompetent husband, but should also continue carrying out her household tasks.' [Female, 49, 01]

In one discussion, participants commented that household activities such as farming were done by every family member, including children, but the community regards these tasks as men's tasks and men are given credit if there is a bumper harvest [K24]. In other FGDs, female participants commented on the double burden that involvement in productive and reproductive work posed for women:

'Women also take part in the activities that are done by men; however they do not get any assistance from men when they do their perceived chores, and this becomes hard for women.' [Female, 36, K9]

In the FGDs, participants identified situations in which they considered men and women to be lazy. This attribute was ascribed to men who were not providing for their families as well as to women who did not fulfil their allocated domestic tasks.

Uyu murume isimbe chaiyo: This man is a really lazy man [K24, most resonant saying].

One all-female group identified this saying as most resonant in their community because women usually took part in both income-generating and household chores without any help from their male counterparts.

'Women are the ones who actively participate in both unpaid and paid work.' [Female, 32, K24]

Participants observed that the men in the community would disagree with this saying, as they would perceive it as a reprimand or a challenge to the status quo.

Women, in turn, were considered lazy if they did not fully carry out their care responsibilities, other activities notwithstanding.

'Even if both husband and wife work in the field, the wife cannot return home and expect not to cook - this shows laziness.' [Female, 68, 01]

\section{- Children, especially girls, should participate actively in UCDW.}

\section{Girls took on the lion's share of household tasks assigned to} children, as evident in the lists of chores assigned to boys and girls in the hypothetical households (see Table 1). In one mixed-sex group, participants concurred that girls, because they are always with their mothers, adopt the same responsibilities [K20]. In an all-female group, reflecting on the typical family they had described, a participant noted, 'Peter, the first child, did not partake in as many household chores during his early years as others because he is male' [Female, $30, \mathrm{~kg}$. Participants also observed that girls are raised to follow in their mother's footsteps by doing household work from the age of five onward [K9]. The discussions around the activities that children and young people were carrying out suggests that norms around age as well as gender were influential in shaping the distribution of tasks within households.

Expectations of children adopting their parents' behaviour is evident in sayings the participants identified as resonant within two communities:

Isigogo sigoqwa sisemanzi: One has to be groomed/trained at a tender age [B11, B15, identified as most resonant]. Another variant of this was:

Umthwentwe uhlaba usamila: One (a child, whether male or female) has to be groomed at a tender age

[B11, B15, most resonant].

Udiyo lufuze imbiza labantwana): Like mother like daughter, like father like son [B11, B15] 


\section{TABLE 1 ILLUSTRATION FROM GILSTON FARM FGD OF THE GENDERED DISTRIBUTION OF LABOUR, BY AGE}

\begin{tabular}{|c|c|c|c|}
\hline \multicolumn{2}{|l|}{ Males } & \multicolumn{2}{|l|}{ Females } \\
\hline $\begin{array}{l}\text { From } \\
\text { what age }\end{array}$ & Responsibilities & $\begin{array}{l}\text { From } \\
\text { what age }\end{array}$ & Responsibilities \\
\hline 2 & Assists mother and older siblings to fetch water & & \\
\hline \multirow[t]{13}{*}{6} & Herds cattle & 6 & Cooks easy meals for household, such as porridge \\
\hline & Fetches and chops firewood & & Fetches water \\
\hline & Directs ox-drawn plough & & Washes dishes \\
\hline & Chases monkeys from fields in farming season & & Cares for younger siblings \\
\hline & Washes own clothes & & Waters vegetable garden \\
\hline & Tills the land & & Tills the land \\
\hline & & 8 & Cooks sadza, the main meal for household \\
\hline & & & Sweeps house \\
\hline & & & Washes dishes \\
\hline & & & Fetches firewood \\
\hline & & & Washes and irons clothes for household \\
\hline & & 10 & Works in field \\
\hline & & & Bathes younger children \\
\hline \multirow[t]{6}{*}{11} & Fetches water using scotch cart & & \\
\hline & & 12 & $\begin{array}{l}\text { Teaches younger siblings, especially girls, to do } \\
\text { household tasks }\end{array}$ \\
\hline & & 15 & Handles ox-drawn plough \\
\hline & & & Engages in paid work on farm, harvesting tobacco \\
\hline & & & $\begin{array}{l}\text { Supervises household tasks done by younger } \\
\text { children }\end{array}$ \\
\hline & & & Sells firewood nearby \\
\hline
\end{tabular}

\section{- Men should be responsible for engaging in productive and income-generating activity to provide for their family's needs.}

The role of men as providers surfaced frequently in the FGDs, even though participants were not asked explicitly to address it.

'As men have the responsibility to be heads of households, they should continue to provide for families. Household work is secondary to family provision and the latter is men's prime task.' [Male, 57, 01]

Perceptions of men who were involved in UCDW appeared to hinge in part on whether the men were also fulfilling their role as a provider. If men in such households engaged in paid work, they were perceived as 'family men' [K9] but if they did not, then they were labelled as 'useless men' [K9, 01, K20] or called lazy and disorganized [01].

Understanding of what 'good men' do is captured in the following sayings, which participants in two FGDs identified as most resonant within their respective communities:

Ava ndivachibhiribhidhe: This is a busy man, a man who is always busy working to provide for his family [K20].

Mukadzi kana murume chaiye chaiye anochengeta mhuri yake: A good man will provide for his family's needs [01]. 
- It is generally unacceptable for men to engage in most types of UCDW.

It was generally considered unacceptable for men to engage in most types of UCDW. While some participants reported positive consequences of male involvement in care, particularly in all-female focus groups - e.g. fostering greater family unity and love, allowing more time for rest and for income generation at home, a reduction in domestic violence [B11, B15] - and commented that in an ideal household, men and boys should take part in domestic work [K9], participants concurred that only a few members of their community would respond positively to men taking on care tasks [K9, B11, K20, K24] and that most would shun such households [K9, K20, 24].

The discussions also attested to sanctions for transgressing norms around male involvement in UCDW. The word 'bewitched' surfaced in each of the discussions [B11, B15, 01, K9, K20, K24]; the terms 'love potion' [B11, B15, K9], 'weak' [01, B11, B15] and 'foolish' [K9, K20] were also used.

In one all-female FGD, a woman noted that men who engaged in care work were said to have been given a love potion and were liable to be laughed at; she noted it was considered abuse of the male role [Female, 61, B11].

'If a man is seen doing unpaid care and domestic work, he will be labelled as a weak man who has been bewitched through love potions.' [Male, 60, K20]

'In such households, if they exist, the wife has definitely bewitched the man.' [Male, 57, 01].

'If the community sees a man sharing care and domestic work with his wife, we conclude that the man has been bewitched/made soft by love potions, or he is simply a weak and stupid man.' [Female, 48, K9]

The recourse to supernatural forces demonstrates the extent to which such behaviour is viewed as aberrant.

Women in households where men took on unpaid care work were described either as absent, e.g. 'Perhaps she is deceased or ill' [Female, 72, 01] or as lazy [01, B11, B15, K24], and their husbands were described as worthy of sympathy, e.g. 'The community sympathizes with such households' [Male 57, 01].

The description of the types of male involvement in UCDW that were relatively more permissible is revealing of the strength of norms regarding male behaviour, but also points to activities which strategies aimed at change could build upon (see Annex 5 for rankings of acceptability across selected FGDs).

Participants disclosed that it was more acceptable for men to do UCDW where this could be done using equipment or when this took place behind closed doors.

The tasks perceived as most acceptable for males included fetching firewood and water - indeed, it emerged in two FGDs that men were already engaging in these activities, as a result of resource scarcity [K9, K24]. The use of equipment to carry out these tasks was cited as one reason for this, with participants noting that men could use carts and wheelbarrows, making it 'easier for them' [B11, B15], and also that most households had taps nearby [B11]. The fact that such activities were relatively less visible also emerged:

'It is easy for men to fetch water using animal-drawn carts, and not to have to carry the water buckets on their heads. By using carts, no one sees them.' [Female, 39, B15]

'Men feel ashamed if they go to the borehole to do laundry when everyone is watching, they can only tolerate ironing since it is indoors, and no one can see them.' [Female, 25, B15]

Other care tasks - notably bathing children, but also laundry, changing nappies, sweeping the house or compound, and cleaning the house - were the least acceptable activities.

'Changing baby nappies, bathing children and sweeping the house/compound are degrading to men.' [Male, 57, 01]

Particular attributes that participants cited were the visibility of these chores and their degrading character. Men who took part in them would be subject to ridicule, or perceived as 'a laughing stock' in their community or as having taken 'love potion' [K9, 01]. In an all-female group, participants observed that doing these tasks would make men look weak and insufficiently manly - whereas tidying beds was relatively more acceptable as they would not be seen in public [B11]. In a mixed-sex group, male participants expressed different opinions over the acceptability of changing nappies:

'I agree that women require assistance with household tasks and [men] can cook or do laundry. However, I carry out these tasks out of my own free will and in exceptional cases, such as when my wife is not feeling well. There are some household tasks that I will not carry out, such as changing a baby's nappy.' [Male, 57, 01]

'How different is cooking from changing a nappy? And besides, these days there are disposable nappies so I cannot leave my child to get a nappy rash when I can change him/ her.' [Male, 42, 01]

The bathing of children received mention in two focus groups $[01, \mathrm{~B} 15]$ - with suggestions that a man bathing his daughter could be construed as abusive [B15].

- It is more acceptable for women to engage in productive or income-generating activities that are 'not too heavy' and that accommodate child-raising and domestic activity.

The engagement of women in productive and incomegenerating activity emerged frequently in the discussions, notably as a reaction to the economic hardship the country was facing. Participant opinions on this appeared to vary markedly; younger men and women tended to describe this tendency more positively, while older participants often espoused more negative views. 
'Households in which women are doing more productive work have no males in them, because no man would allow that. Women who do these tasks are either widowed or divorced.' [Male, 57, 01]

Some participants highlighted that men in such households had failed to control their wives and were being bullied by them [B11, B15].

For women, the most acceptable productive tasks included farming, chicken rearing, and paid activities such as doing laundry for others or working at the local council (see Annex 5 for rankings of acceptability across selected FGDs). Across the discussions, the key characteristic shaping acceptability was the perception that tasks did not require physical strength [01, B11, B15, K9] - acceptable activities were described as 'softer', 'easy', 'not too heavy', and would not require too much power or energy. Conversely, the least acceptable tasks including carving, construction, fencing, cutting wood, gold panning - were those which participants felt required physical strength and would show power or independence.

'Women can carry out tasks deemed for men such as chicken rearing, farming and engaging in paid work such as doing laundry for others, because these tasks do not require much physical strength.' [Female, 42, 01]

'Women do not do tasks such as house construction, digging wells, using scotch carts, fencing gardens and chasing monkeys from the field.' [Female, 53, 01]

The ability to combine farming or paid work with childcare or other household chores also emerged - with female participants noting that farming could be combined with childcare [Female, 54, B15], and that housebound incomegeneration projects, such as chicken rearing, were easier for women than going from place to place in search of work [Female 48, K9].

Some tasks, such as cattle herding [B11] or selling furniture [B15], were simply described as 'male' with no explanation offered other than allusions to culture.

- It is unacceptable for a woman to forego her unpaid care and domestic responsibilities, even if the household is in a position to pay for these services to be provided.

In all the discussions, participants cast women who did not fulfil their expected care roles in a very negative light. In addition to being called lazy, they were described as shameless [B11, B15] unpopular ('regardless of the circumstances'] [01, B11, B15], social misfits [B11, B15] and isolated from other women [01]. Descriptors included 'outcast', 'uncultured woman' and 'prostitute' [B11, B15]. Such women did not show due deference to their elders [B15] and should be censured.

Girls might be subject to the threat of violence:

'Women who do not do care work are isolated from other women. If it is a girl who does not do care work, then she is beaten up by her parents, though this is rare because most girls just do care work.' [Female, 42, 01]
Married women who did not do care work could be subject to complaints from husbands' relatives [B11, B15, 01] as well as divorce [01], or their husbands would be encouraged to marry another wife. Unmarried women who did not fulfil expected care roles were described as unmarriageable. There was agreement that the community would criticize and condemn such women.

For example, according to participants in two FGDs, if a woman does not do expected duties, she might be shunned by her husband and by her in-laws or community. Most community members will not feel comfortable being associated with her as she will be considered an outcast, a lazy and uncultured woman [B11, B15].

One middle-aged male expressed some support for women who were in a position to employ household help: 'I think this is a good idea because it gives women time to rest' [Male, 42, $01]$. However, the general view was that even in such cases, women should continue to do household tasks [K9, B15].

'As a woman, you should do the chores even if you have a helper. The girls who are not doing household chores put a spotlight on their parents as they become the laughing stock of the village or community at large.' [Female, 42, B15]

Gendered social norms (and norms around age) were reflected in a set of shared understandings concerning the roles of women, men, girls, and boys, in the selected communities. These underpinned a distribution of labour in which women (and girls) were responsible for reproductive work, and men for providing for their families. The acceptability of male engagement in UCDW and female engagement in productive work was tightly circumscribed, and it was considered completely unacceptable for women to relinquish their care responsibilities.

\section{Beliefs underlying the distribution of work}

Beliefs play a powerful role in shaping and perpetuating shared expectations regarding the traditional roles assigned to females and males in the selected communities.

Accordingly, participants were asked to explain the reasons for the prevailing gendered division of labour.

Participants ascribed the unequal distribution of labour to cultural expectations [01, B15, K9] and biological differences [01, B11, B15, K9].

'The division of household work is culturally based. Women are expected to carry out household tasks, whereas men are supposed to fend for the family.' [Male, 57, 01]

'Culturally, men are heads of households and can therefore not engage in women's work. Doing so makes them appear weak/insignificant to their male counterparts.' [Male, 46, 01]

'It is a taboo in the community to see men doing women's work, as they will be considered as weak and unable to make decisions in their households.' [Male, 59, B15] 
In one group, participants expanded on these twin explanations. An older man observed that some activities are expected to be done by boys, such as looking after livestock and going to the cattle dip, and therefore boys cannot be seen lingering in kitchens. They can just help the girls and women if there is need, but otherwise women can manage to do the household chores [Male, 59, B15]. An older man commented that 'the work is divided like that because women were made and are expected to do household chores, and men were meant to do heavy tasks only' [Male, 68, B15]. An older woman echoed this view, emphasizing that since they were born, they were taught that there are men's activities and women's activities [Female, 57, B15]; another younger woman added that men are strong and that is why they are doing heavy activities and leaving light chores for women [Female, 39, B15]. Participants also commented that they had grown up with these values and therefore were not amenable to change [B15].

However, some participants' remarks also reflected a slow process of cultural change:

'Long ago, culture did not allow women and men to sit in the same room or to find men in a kitchen. Things are slightly changing, as we now see men being cooks and being able to clean the house.' [Female, 51, B15]

'What is happening now was not there when we were growing up, a boy long ago would not be seen in the kitchen. Even if he saw that there was no water in the house, he would not help - he would rather wait for women to collect water which he would want to use also. This was called grooming him to be a man and husband.' [Male, 59, B15]

The male participant quoted above added that nowadays men and boys are doing some household chores, though change is slow as some men still believe that it degrades their manhood to be seen fetching water and cooking.

The persistence of gendered patterns of distributing work was ascribed to cultural expectations and biological differences, notably the need for women to engage in 'lighter' forms of work. Participant remarks also reflected a slow process of cultural change.

\section{'Economic norms' underlying productive and reproductive work}

In one exercise, participants discussed perceptions of the 'skills' and 'value' attributed to care work and productive or income-generating activities. This revealed that UCDW is generally perceived to require relatively fewer skills than productive activities and to be of relatively less value, although the care of children was valued highly.

\section{How skill is assigned}

Across the groups, participants identified house construction and repair as the task requiring the most skill, followed by planting and harvesting, and caring for the elderly, ill and disabled (see Annex 4, Table A.2). The task perceived to need the least skill was cleaning the house or compound, followed by meal preparation, and the drying and processing of agricultural products.

Of seven types of tasks that participants believed to require the most skill, five were farm/productive activities (12 mentions) and two were care activities (four mentions). Of the nine tasks considered to require the least skill, five were care activities (13 mentions) and four were farm/productive activities (five mentions).

Participants drew on the following criteria to explain why some tasks required relatively more skill:

- The association with expertise, equipment and qualifications.

- Their contribution to people's safety and survival.

- Their importance in sustaining life.

In three of the discussions, participants remarked on the expertise and education needed for house construction, in order to build strong and proper structures, as well as for carpentry [B11, B15, 01]

'Most tasks done within the home, such as cooking and cleaning, are not as important as house repair/construction because they do not require special training; therefore that is why women do them.' [Male, 57, 01]

In that same discussion, participants agreed that activities such as carpentry required special skills, unlike domestic tasks such as cleaning the house [01].

'Activities such as carpentry require special training at institutions such as Domboshava Training Institute, and also bring income.' [Male, 57, 01]

Similarly, in another focus group, participants explained that planting and harvesting required equipment and expertise [B11], while the drying and processing of agricultural products only required appropriate equipment and correct temperatures [B15]. Along similar lines, participants agreed that taking care of farm animals was an unskilled activity because it did not require any specialized animal husbandry, but simply needed water, shelter and the right medicine [B15].

However, these arguments gave way to some debate. An older woman told her group that the planting/harvesting of crops needed skill because a lot of instructions had to be followed to attain a harvest [Female, 57, B15]. Another woman noted the need to add value in processing, which an unskilled person cannot do, and therefore identified a need for schooling [Female, 60, B15]. In both cases, other participants offered counter-arguments. One woman stated that planting and harvesting had taken place over a long period in which people were not going to school to learn about it, showing that such schooling was unnecessary [Female, 51, B15]. She also emphasized that drying and processing was not a skilled activity because people were trained in it by their elders [Female, 51, B15]. Another participant supported this argument, stating: 
'The traditional drying of vegetables does not need formal schooling as we are taught the art of vegetable drying by our grandmothers.' [Female 57, B15]

Beneath these remarks, it is evident that what counted as 'skill', as 'valuable' or as 'training' involved formal rather than informal forms of learning. Along similar lines, in explaining why some tasks were perceived to require relatively fewer skills, participants typically argued that the requisite abilities were innate or ingrained in children from a young age. In one focus group, participants agreed that cleaning of the house or compound required the least skill because women were nurtured to do household chores without any skills [B15].

'Mostly women's work such as sweeping, cooking and taking care of children is considered to need less skill because it is an activity that you are born to, therefore no skill is required.' [Participant, B11]

'Cooking is a skill that women are taught by their mothers as they grow, whereas tasks such as carpentry/furniture require more skill as they are done by men.' [Female, 72, 01]

A second criterion for attributing skill to a task was its contribution to safety and survival. In two of the all-female discussions, participants justified their selection of different sets of activities (in the first case, caring for children, planting/ harvesting, and taking care of farm animals; and in the second, planting/harvesting, house construction, and care of the ill, elderly or disabled) by pointing out that these activities were crucial to the survival and safety of families [K9, K24].

'If a builder does not have skill to do his/her job, it puts the users in danger if the building collapses.' [Female, 39, K24]

'If people do not farm skilfully, then there will be no food which is vital for survival.' [Female, 44, K24]

Finally, some participants argued that some activities required more skill than others because they were important to sustaining human life - in particular, the care of children, which would have a large bearing on their future [K9], and care of the ill, elderly and disabled [K20].

'It is important to teach children what is socially expected of them by the community as well as in the family.' [Female, 34, K9]

'Child protection is more important than looking after one's domestic animals because for one to be recognized as a member of good standing in the community, one is raised by one's parents and siblings.' [Female, 40, K9]

'Caring for the sick, the disabled and the elderly requires skill because such responsibilities have a bearing on human life, and it is different from sweeping the house where you can ask a little baby to do the task.' [Male, 21, K20]

'Taking care of the sick and elderly is more important than cleaning the house.' [Male, 65, K20]

In three FGDs, participants reflected on why mostly male tasks were considered skilled, and mostly female tasks were considered less skilled. Two of the groups reflected on how women were steered towards light, 'unskilled' chores, whereas men went to school to acquire skills to carry out tasks such as building and carpentry [B11, B15].

In one mixed-sex FGD, the gendered aspects of tasks and the skills attributed to them received some attention. A young man highlighted that long ago, only men were required to have skills in certain jobs as they were considered family breadwinners, whereas women's activities are light, requiring no skills [Male, 18, B15]. A middle-aged woman argued that women were looked down upon and it is still happening, which is why men's jobs are associated with high skill and so-called women's work is seen as having no skill [Female, 51, B15]. A middle-aged man opined that things are changing slowly such that women are now found with the skills mentioned - but that women are not yet taken as seriously as men. In his view, even women themselves do not support each other but would rather support men [Male, 56, B15].

In another FGD, men generally argued that domestic tasks mostly done by women require less skill, whereas women argued that domestic tasks require a lot of skill [01]. This gave way to some debate, which is evident in the following statements:

'Household tasks can be done by anyone, whereas activities such as house construction/repair require special training and certification.' [Male, 36, 01]

'Although men may argue that cooking requires no skill, women who are unable to cook are sometimes at risk of being divorced by their husbands.' [Male, 42, 01]

'Cooking requires as much skill as carpentry because people do not enjoy eating badly prepared food.' [Female, 44, 01]

'Cooking and other domestic tasks such as cleaning the house do not require much skill, therefore house helpers earn little money. This is because people who do not engage in these tasks are simply busy - it is not that they cannot do these tasks.' [Male, 57, 01]

\section{How value is assigned}

Participants felt that the planting and harvesting of crops was the most valuable activity in their community, followed by care of children, mentioned in four groups, then by meal preparation and fuel or water collection (see Annex 4, Table A.3). The least valuable activity was identified as carpentry, followed by the selling and trading of products.

Participants explained that the value they assigned to tasks was based:

- Firstly, on the task's connection to immediate survival needs. - Secondly, on its potential for income generation.

The planting and harvesting of crops and access to water were identified as prerequisites for survival.

'Farming is very important as it puts food on the table as well as bringing in an income for our survival.' [Participant, K24]

'Water is the basis of our existence. If we do not have water, we have no life.' [Female, 33, K9] 
'Water is the source of life; hence for all other activities to be able to take place, water has to be available first.'

[Participants, K9]

Along similar lines, women in an all-female discussion assigned less value to the drying and processing of agricultural products, explaining that because they had vegetable gardens, they could survive without this [B11].

It was argued that caring for children had value, given that lives were involved and that children represent the future [B11, B15, 01].

Across the discussions, participants pointed out that besides providing food, farming was also a source of income [B11, B15, K20, K24].

'Farming is the basis for life because we gain food and raise income for selling agricultural produce' [Female, 48, K20]. The view of this participant was supported by all other participants in her group.

Conversely, tasks were assigned less value if they did not relate as directly to survival needs.

In one discussion, participants established that meal preparation was not as valued as planting and harvesting, because to get the food to cook, it would first need to have been farmed [K24]. In another, participants agreed that carpentry/making furniture was the least valuable activity because it is not a means of food production, and also because furniture is not frequently bought in their ward due to limited resources [01]. Similarly, in an all-female group, participants agreed that carpenters were not in high demand [B11]; carpentry was regarded as a luxury which could be done without, and something which can be bought [B11, B15].

Some disagreements arose in the discussion of value. For example, in one focus group, there was general consensus that taking care of farm animals was not a valuable activity ['You can replace animals, but you can't replace children,' Male, 18, B15]. An older man took issue with this, arguing that culturally if a household did not have livestock or lost them due to negligence, it would be considered poor [Male, 59, B15]. A female participant disagreed, arguing that so long as food and water are available, and children taken care of, other activities are secondary.

In the mixed-sex groups, there was discussion of the gendered aspects of what was considered valuable and participants expressed diverse views, which often broke down by gender.

In one discussion, male and female participants debated this for a very long time. Women argued that household work, although regarded by men as basic and requiring no special skill, is very valuable as it brings stability to families. But they felt this was not recognized [01]. Participants generally agreed that society does not value domestic tasks because they are culturally expected to be done by women. Society values tasks that are traditionally prescribed as men's work; the exception to this is caring for children, given that generation-building is important to the community [01]. Men argued that productive tasks were more valuable.

'Home chores are important to family life and sustain and maintain the family.' [Female, 46, 01]

'Cooking and laundry can be done by any person and require no special training.' [Male, 57, 01]

'Even a person who engages in productive work requires someone to cook for them at home for survival.' [Female, 40, 01]

'Household tasks are mainly done by women and are not recognized, as well as being unpaid.' [Female, 34, 01]

However, some exceptions to these gendered perspectives were also evident, as the following statements attest:

'Women's work is valuable; that is why culturally a cow is given to a mother's family when her daughter has bride price paid for her.' [Male, 42, 01]

'Activities that are done by us uneducated women are not very valuable. Valuable tasks are those that take place outside the home, which our grandchildren are leaving villages to acquire training in.' [Female, 72, 01]

Skill was assigned primarily based on the perceived need for formal schooling or training. This resulted in a denigration of the skills required for care activities traditionally taken on by women, many of which were acquired through informal forms of education and training in the home, often from an early age. The remarks reflect assumptions that women 'naturally' and 'normally' have skills for care activities, undervaluing the effort required to obtain these skills. Value was assigned primarily on the basis of the perceived contribution of an activity to survival needs - participants felt that farming was particularly valuable on this basis, as well as the care of children.

\section{Change over time}

Participants were asked to identify and discuss any changes in the household division of labour, both temporary and permanent, which had taken place, what led to these changes, and what were the effects. Their reflections suggested slow processes of underlying norm change, which were intersecting with changing realities brought about by economic hardship and resource scarcity. The discussion also demonstrated circumstances which gave way to short-term shifts in the productive and reproductive activities carried out by women and men, with some evidence that these shifts were becoming more frequent.

\section{Long-lasting change}

In four of the six communities, FGD participants agreed that there had been a long-lasting shift in the gendered division of labour within households, though this was not always recognized or accepted. In the other two communities, participants agreed that no long-term change had occurred, owing to a lack of knowledge about how to bring about change $[K 20, K 24]$ and a lack of courage to challenge traditional household roles [K24]. 
In three FGDs, participants focused on greater female engagement in income-generating or productive activity [01, $\mathrm{B} 11, \mathrm{~B} 15]$. In two communities, participants highlighted that men had previously been the chief breadwinners, seeking employment in mines, but now women had also become artisanal miners [B11, B15]. In one of these communities, participants commented that it was currently acceptable and normal for women to be formally employed, and that there were homes where the breadwinner is a woman land the man is not working). Participants cited the rise of cross-border trading by women [B1l] as well as broader instances of changing female activity, for example with women driving, emigrating, attending community meetings, participating in politics and being in leadership positions [B11].

The shift towards increased female involvement in productive and income-generating work was also revealed in discussions around the most resonant saying in one community - mukadzi kana murume chaiye chaiye anochengeta mhuri yake: a good man will provide for his family's needs. While men and older women felt that this saying was particularly resonant, some focus group participants felt that the saying was becoming less relevant, given that an increasing number of men were unemployed and unable to provide for their families [01].

Positive drivers of change identified by participants included: female education [B1]], community-level awareness-raising programmes $[\mathrm{B} 11,01]$, a desire for happier marriages, increased access to labour-saving equipment, and more resources for household help owing to spouses working in the diaspora [01]. However, participants also pointed to negative factors: economic hardship leading to male unemployment and migration, greater female participation in paid work [01, Bll, B15], and the growing scarcity of fuel and firewood [K9]. It is notable that (long-term) migration was discussed mostly in relation to men rather than women, in marked contrast to circumstances in many other countries.

'For us, the younger generation, [women engaging in productive work] is now the reality because of high unemployment rates.' [Male, 36, 01]

\section{Participants perceived some benefits of greater female} involvement in paid work for women, including increased self-esteem, the option to buy property and to contribute to community affairs, and the ability of single women to support their families (including elderly relatives) rather than rely on handouts from relatives. In one all-female focus group, a division of opinion arose between younger and older women. The younger women argued that rising female labour-force engagement was positive for families and communities, while older women cited negative consequences including domestic violence, divorce, increased promiscuity and children growing up under the care of maids [BIl]. In another FGD, some participants reported that women were neglecting their roles and responsibilities in 'chasing money' rather than looking after their families [B15].

While participants pointed to the need for women in paid work to continue taking on UCDW, other obligations notwithstanding, they also highlighted some instances of increased male involvement in care. For example, in two FGDs, participants remarked that men had started to fetch water and firewood, and had been seen washing and ironing clothes in their households [B11, B15]. Some participants directly cited the link between women working and men's adoption of some care tasks:

'If your wife goes to do part-time work, you are then forced to cook because you cannot starve yourself or the children.' [Male, 36, 01]

'Employment opportunities these days are on a part-time basis and men are not comfortable doing these jobs, such as doing laundry for other families for a small fee. Therefore, it is better that if I return home I find my husband having cooked or bathed the children, because I will be tired.' [Female, 44, 01]

Across the FGDs, participants highlighted some positive consequences of male involvement in UCDW for families (e.g. helping husband and wife to be close to one another) and for men - including a feeling of contributing to the household (if not otherwise working) and receiving more love from their children because they spent time playing with them. However, some men felt that involvement in UCDW was difficult to reconcile with traditional expectations of men as providers, suggesting that changes in behaviour wrought by economic hardship were outpacing changes in gendered norms:

'At times, it is very hard to accept as a man that I cannot provide for my family, so I just end taking up some of the household chores so that I can be useful around the house.' [Male, 57, 01]

'We do not openly talk about doing these [care] chores to other people surrounding us, such as family members and female relatives. We also make sure that when there are visitors around, we do not do these chores.' [Male, 50, 01]

In another community where participants believed that there had been long-term change, discussion in the all-female group focused on fuel and water scarcity and men's increasing involvement in their collection [K9]. Participants explained that these commodities had become scarce within the last 10 to 15 years, and that the Environmental

Management Agency had forbidden cutting down trees. This rendered it necessary for community members to travel long distances to obtain the little fuel they used land in some cases 8-10km to fetch clean water). The discussion revealed that men were now active in collecting these commodities, though there was some disagreement over the extent of this 
shift. Some participants felt there had been no significant change, while others felt that, however limited, male involvement represented a meaningful change from the past:

'Yes, men and boys are now helping us to find wood and water, but the burden of care work is still carried by women.' [Participant, K9]

'The sharing of care work is the change that is happening, as in the past men did absolutely nothing.' [Participant, K9]

\section{Temporary or seasonal change}

Participants also reflected on seasonal or temporary changes in the division of work roles experienced in their communities - in all but one FGD [K20], groups were all able to point to changes in reproductive or productive roles at certain junctures. It should be noted that the line between longlasting and temporary change is not necessarily clear: participants reported that some forms of 'temporary' male engagement in UCDW were considered more acceptable than had been the case in the past. In one FGD, it was remarked that men were now taking part in care tasks like cooking when the woman was not at home, was heavily pregnant or had recently given birth - whereas in the past men did 'not even wash their underwear' $[B 11]$.

\section{-Women's engagement in farming}

Typically, the farming season (from October/November to March) heightened demands on men and on women ['In summer time, the work is increasing,' Female, 46, 01]. However, girls and women faced a dual burden of engagement in both productive and reproductive work:

'After a long day at the field, we return home and my husband puts his legs up and expects me to start preparing food.' [Female, 44, 01]

'During the cropping season, girls still have to carry out additional tasks as they are not exempted from household chores, unlike boys.' [Female, 46, 01]

Another participant in this group pointed to the consequences for girls in particular, i.e. falling behind on schoolwork or having to drop out of school [Female, 42, 01].

\section{-Women's seasonal engagement in paid work to supplement household income}

Outside of the farming season, participants in one FGD highlighted female involvement in income-generating activities such as buying and selling - though they reported that the older generation condemned such activity, believing it was a man's duty to take care of a family's financial needs [K9].

\section{- Resource scarcity}

In two communities, participants reported that most men and boys assisted with collecting water in the summer because wells had dried up [K9, K24]. Some participants felt this change would last for as long as there were problems with water and firewood collection - whereas others felt the
The mixed views of FGD participants towards female engagement in income-generating activities was revealed in a discussion around the most resonant saying in one community:

Uyu mukadzi mudealer/gweja: This woman is a dealer/hustler [K9, contemporary saying]

Participants agreed that this saying resonated highly in their ward, particularly with young people, as most women were in fact providing for their families through buying and selling, and younger women see this as a role they can take on. However, they felt that elderly men in their community would reject this saying, out of a belief that women should not be active in earning income; and women would be most accepting, as it encourages them to work. It should also be noted that 'hustling' in Zimbabwe does not have a uniformly positive connotation; it is not considered to be an activity in which 'dignified' women engage. 'Good' women will work hard and earn an income through mainstream vending, while women who 'hustle' might engage in cross-border trading, deal in foreign exchange or money changing, sell gold or drive 'pirate' taxis.

change would be long-lasting because men and boys were now used to participating in this task [K9]. They concurred that the community has accepted this change because it came about owing to problems they all faced [K9].

\section{- Illness, pregnancy, soon after giving birth}

In three FGDs, participants pointed to increased male involvement in care work if their wives were ill or pregnant, or directly after childbirth [01, B11, B15] - both because she would not be physically able to undertake tasks like cooking, and because 'culturally [women] are not allowed to cook after giving birth' [B11].

I agree that women require assistance with household tasks and [men] can cook or do laundry. However, I carry out these tasks out of my own free will and in exceptional cases such as when my wife is not feeling well. There are some household tasks that I will not carry out, such as changing a baby's nappy.' [Male, 57, 01]

However, in one FGD, participants qualified this remark, observing that this was only true if there were no other women or grown children at home who could take on care roles in the wife's absence [B11].

The discussion of long-term processes of change pointed to some changes in male engagement in reproductive work and female engagement in productive work, behaviours triggered primarily by economic hardship causing more women to take up paid work. Norms appeared to be adjusting relatively slowly to this new reality. 


\section{PART 2 - EVIDENCE OF APPETITE FOR CHANGE}

This section of the report describes evidence pointing to some desire for a more equitable distribution of labour, and steps that could be taken to further processes of change. It conveys participant perspectives on the consequences of the existing division of care work, and the desires that some participants expressed for a more equitable division of UCDW. Then it outlines participant views on the most compelling ways of communicating messages within communities, and the concrete steps they identified to foster an alternative division of UCDW among the younger generation.

\section{Consequences of the division of UCDW} Many participants, particularly females, highlighted negative consequences of the unequal division of household work for women. Most often, these involved concerns over health [01, $\mathrm{K} 9, \mathrm{Bl1}, \mathrm{B15}]$, notably 'getting old too quickly' [K9, 01, B12, $\mathrm{K} 24]$, backache $[01, \mathrm{~K} 9]$ and the increased likelihood of sickness [B15, K9, K24]; with specific mention of high blood pressure, depression, miscarriage and chronic disease [B15].

'Women carrying out housework, working the land as well as engaging in short-term paid work results in them having bent and aching backs due to being overworked.' [Female, 42, 01]

'Because women start doing household chores at the tender age of five, they are easily affected by conditions such as backaches and get old more quickly than men because they do not get time to rest.' [Participant, K9]

'We would like to have rest time, however, because we are always expected to work, we hardly ever have time to rest.' [Female, 45, K24]

'Due to lack of rest, women are very prone to diseases.' [Female, 53, K24]

Participants also raised concerns regarding the impact of heavy and unequal UCDW on family life - including intimacy with husbands [01] and psychological wellbeing [B15]. A young woman observed that if a woman is burdened with care work she ends up being unhappy, resulting in her leaving her husband in order to have freedom [Female, 25, B15]. In that same FGD, an older woman commented that because women have many chores in the household, this makes them look like people who cannot think for themselves. There are so many women who cannot make household decisions in the absence of their husbands, she continued, because they are treated like children and the husband is the only person who makes rules and laws within the household [Female, 62, B15].

The effect on the education of girls of 'always doing household chores' [K9] also emerged [K9, K20].

'When Chipo [girl in 'typical household'] comes home from school she has to assist with household chores and this may lead to her not having enough time to do her school work.' [Female, 35, K20]

\section{A final issue that arose was the lack of time to pursue} income-generating activities [B15].

Some disagreements were evident in the FGDs, which tended to be expressed along gendered lines.

In one mixed-sex group, men disagreed with women when they cited the negative impact of being overburdened with care work, as the following exchange attests:

The men considered that household chores were nothing compared to the activities they did. For example, one man claimed that the digging and clearing of land is heavy and is men's work; it cannot be done by women [Male, 56, B15]. Women, on the other hand, disagreed: one participant commented that women do heavy tasks which are said to be men's work, and that they also do those heavy chores whilst men are drinking beer [Female, 51, B15]. She added that the heavy tasks being mentioned by men were seasonal activities (e.g. clearing land) and they do not do them alone - women are also there - whereas when it comes to household chores, these are a daily activity which cannot be done without.

\section{Desire for change}

The topic of whether a change in the division of household work would be desirable provoked considerable debate within the FGDs. In the three all-female focus groups and, on balance, in the mixed-sex groups, participants - especially women and younger men - favoured a more equitable distribution of household work. However, this met with some resistance, especially from older men.

Participants gave concrete examples of what a more equitable division of UCDW might look like:

'I would want to see men helping with water collection... boreholes in the villages are heavy and therefore if both men and women go together it will be a lot easier to pump water together.' [Female, 57, B15]

'I would like to see my boys washing clothes for the family and helping with cleaning the house. The two that are married, I would like to see them helping their wives, including bathing their children.' [Female, 62, B15]

'I personally want to change and to collect water, wash plates and cook sometimes.' [Male, 18, B15]

'My wife can cook whilst I fetch water at the community borehole using a scotch cart.' [Male, 35, 01]

'After her long day doing care work, I can allow my wife to take a nap whilst I bathe the children. She can wake up to do cooking for an evening meal later.' [Male, 42, 01]

'With the current dire economic state of the country, a man may not engage in paid work but may have good relations with his wife, thereby still making him a good man who assists in household tasks as well as caring for the children.' [Male, 35, 01] 
'On returning from the field, changes in the division of labour do not mean the wife should sit and do nothing. However, the husband can fetch water or light a fire for cooking to enable her to cook.' [Female, 44, 01]

'Younger men do not agree with their forefathers' belief that women should work continuously without resting, because they are also human. Additionally, if a woman engages in paid work she can also pay someone who can assist her with housework.' [Male, 42, 01]

Participants, both male and female, cited many positive potential outcomes of sharing household work more equitably - amongst them, having time for 'storytelling, self-care and rest' [Male, 56, B15], enhancing love between spouses [Male, 18, B15, participants in K9], allowing additional opportunities for income generation [Male, 59, B15], avoiding illness from overwork [Female, 39, B15; Male, $56, \mathrm{~B} 11]$, and more generally, lessening the burden on women [K9, K20, K24].

The desire for change also emerged in the three all-female FGDs when participants were asked what they would do if they had an additional hour each day. In one focus group, all eight participants said they would rest a bit more - sleeping more hours or even taking a nap during the day [B11]. In the other two groups, participants were divided as to whether they would rest (participants agreed that they were not currently getting any rest [K9]) or concentrate on income-generating activities for the benefit of their family [K9, K24].

Some resistance to the idea of change was also evident:

'A different division of work means that men become emasculated - it would be equated to men wearing a dress.' [Male, 57, 01]

'Men are not very good at raising children because it is women's main task, as they have the love and patience for it.' [Female, 46, 01]

Women and younger men tended to be more in favour of a change in the gendered division of labour than older men, who emphasized that the roles of men and women should remain distinct. This difference of views is evident in the following statements:

'A different division of work is a violation of cultural practices and it also causes women to disrespect their husbands, causing gender-based violence.' [Male, 57, 01]

'As the world is evolving so are men, and we are engaging in household tasks such as sweeping. Personally, I have no problem with that.' [Male, 35, 01]

'Men and women doing household tasks together is a good thing which has helped my wife and I to love each other more. I am doing it and it has helped our marriage.' [Male, 42, 01]
'If we as men do more than what we are doing now we will be seen as weak, children will not be able to listen to us and they will not know who the household head is.' [Male, 68, B15]

'The redistribution of care work does not mean you are no longer a man or a father or household head, it means sharing duties and ensuring that burden is not shifted to one person, especially the woman.' [Female, 60, B15]

Although this debate often broke down along gender lines, this was not always the case, as the following exchange attests:

'I do not agree with men cooking because the kitchen is meant for females; therefore, I do not allow my husband to handle my plates.' [Female, 46, 01]

'What then do we do, as some of us men like to cook and do ironing?' [Male, 42, 01]

\section{Looking to the future}

To approach preferences over the division of labour from another angle, participants were also asked about their aspirations for young men and women in their communities, once they formed their own families. Across the FGDs,

participants favoured a more equitable division of UCDW among young people, and for women to have more options to participate in income-generation. This was explained either on principles of equality, e.g. 'Children are equal and should be given equal responsibilities' [Participant, K24] or as a way of adjusting to the realities of the country's socio-economic climate [01].

In one discussion, participants described a hypothetical scenario in which 'David' did laundry while 'Diana' cared for livestock, and they raised their children to share duties regardless of their sex. They envisioned that this couple would be a role model for their children and the broader community [BII]. More broadly, participants expressed the views that that 'David' and 'Diana' should share household chores, 'David' should take part in those activities that were currently considered to be unmanly or degrading, and that he should do so openly.

'[David] should know that there is no activity which is called "women's" but it is for everyone in the household.'

[Participant in all-female focus group, B11]

'I would like for David to know that changing his child's nappy is not a shameful thing - it increases love in the marriage.' [Male, 42, 01]

'I would like to see David doing household tasks whilst his female relatives and peers are at his house.' [Female, 34, 01]

Women and younger men generally desired a more equitable gendered division of labour and gave concrete examples of how this could look. Older men tended to resist shifts in traditional gendered roles. Across the FGDs, participants favoured a more equitable division of work among the young people in their communities, once they formed families of their own. 


\section{PART 3 - STEPS TO INFLUENCE CHANGE}

The third part of this report looks at how changes can be taken forward, drawing on participants' impressions of compelling ways of sharing messages within their communities, and concrete steps they identified that could be used to engender a more equitable division of labour in the future.

\section{Compelling ways of sharing messages}

The sharing of information that prompts different values and attitudes is an important component of interventions aimed at changing norms; in other settings, field research has found that a combination of factual information and broader messaging on gender equality - through mass media as well as popular entertainment programmes - had contributed to changes in gender norms. ${ }^{15}$ With this in mind, participants were asked to identify effective messengers and role models within their communities, and the most trusted sources of information.

\section{Who people listen to and follow}

\section{Asked who people in the community listen to and follow,} participants cited:

- Traditional leaders [K9, K20, K24, 01, B11, B15].

- Religious leaders [K9, K20, K24, B11, B15].

- Village-level workers including health workers, ward coordinators, agricultural extension officers [K9, K24, K20, 01, B11, B15].

- Political leaders/councillors [K9, K20, K24, 01, B11, B15].

- Business owners [B11, K20, K24].

Less frequently mentioned were NGOs [B11, B15], local radio personalities [01], the police [K9], neighbourhood watch and mine owners [B11].

Asked who young people admired, participants mentioned 'those who had achieved something in life' [K24] including successful business people [K20, K24] and teachers [K20] - and in one community, local music personalities such as Jah Prayzah and local dancehall artists [01].

Role models were limited. When asked about men they knew who had taken on household care work, in four communities, participants knew no one [K9, K20, K24, 01] - 'Do such men exist?' [Male, 57, 01]. In two discussions, the all-female participants expressed the view that if respected men engaged in household chores, this would certainly prompt other men to do so [K9, K24]. However, in another discussion, participants concurred that men who did such work did not talk openly about this, such that there were no role models as yet [01]. In one FGD, participants identified a local icon, Ndumiso Gumede, former executive director for Highlanders Football Club. Mr Gumede, who was 65 years old, lived alone and carried out household chores such as fetching water and cooking [B15].

In three communities, people did not have access to radio, TV or newspapers, so could not identify any male characters taking on household care work [K9, K20, K24]. In a community with radio access, participants said that no male radio personality openly talked about taking on household tasks or looking after people [01].

\section{Trusted sources of information}

Participants identified the following as the most effective ways of communicating information:

- Community theatre, possibly in conjunction with soccer tournaments. In several discussions, this was identified as the most effective means of disseminating messages and the most trusted way of receiving them, given that many people attend these events and they occur in the presence of local leaders [K9, K20, K24]. This was mentioned as important for youth.

- Bulk SMS [K24, 01, B11, B15] - also mentioned as important for youth.

- Public meetings [K20, K24, 01].

- Road shows [K20, K24, 01] - also mentioned as important for youth.

- Radio broadcasts [B11, B15, 01], especially to reach older men and women [01], in communities where participants owned radios.

- Newspapers [B11, B15].

- Posters [K24].

- Songs [K20].

- NGO workshops [01].

In one community, television and WhatsApp were described as 'least effective', and the internet as the 'least trusted' information source [01]; this was echoed in two other discussions, where participants expressed the view that information circulating on social media was distorted [B]1, B15]. However, in these latter two discussions, participants also commented that for young people, internet-based channels such as Instagram, WhatsApp, Facebook and text messages were important [B11, B15].

FGD participants identified a wide variety of trusted messengers in their communities and ways of communicating messages, though role models (men taking on care roles) were in relatively short supply. 


\section{Supporting change}

Across the FGDs, participants widely agreed that:

- Parents should treat boys and girls equally, so they had the same chance to reach their potential and would grow up with the ability to participate in all tasks [B11, B15, K20, K9, K24].

- Women should have more opportunities to engage in incomegenerating activities [K9, K24].

They commented that parents should start to support change by dividing chores equally among their children without focusing on gender [K9, K20]. Participants agreed that young boys should also be taught by their mothers to engage in household tasks such as cooking and fetching water, so they would not struggle as bachelors and could carry out their own tasks while they search for a spouse [01]. Girls, in turn, are nurtured to concentrate on household chores [K9]. From an early age, they need to be taught to be aware of their capabilities and full potential, so as not to underestimate themselves [K9, K20], and to be aware of income-generating possibilities. Participants agreed that encouragement and changes in thinking were needed for girls to have the courage to pursue their ambitions, and that this would require active efforts from parents, teachers and the community [K20, K24].

For men like 'David', participants identified the following support as necessary:

- Training at an early age - e.g. at the primary level [B15, B1], 01]. Such training should inform men about what women would really think about a new division of labour [01].

- A platform to identify like-minded men [01].

- Support from like-minded men [01].

In addition, in one all-female FGD, participants agreed that while an equal distribution of work might not be feasible among the older generation, older men might be willing to assist in some tasks such as collecting firewood [K9].

In one FGD, participants also recognized that women would need to change their mindsets regarding male involvement in unpaid care - observing that women themselves do not value men who do UCDW and may gossip about their husbands when they do so [01]. This is revealing of female complicity in perpetuating norms that prescribe against greater male involvement in UCDW.

'As men we can carry out household tasks - except changing nappies, because our wives will speak ill of us to the rest of the community if we do so.' [Male, 57, 01]

Participants observed that if care work is redistributed, there is no need for this news to be spread around the community as if something is amiss, and that 'Diana' needs to know that she should respect her husband even if he does UCDW, and should not go around telling her friends in a demeaning way that her husband does care work.
Participants identified steps that parents could take to foster a more gender-equitable distribution of work among young people so that they would model this behaviour as adults, including ensuring the equal treatment of boys and girls and encouraging girls to reach their potential. The discussions also highlighted female complicity in patriarchal norms, and the need for a change in the mindsets of women as well as men toward male involvement in UCDW.

\section{Implications}

As stated from the outset, the objective of this study is to inform Oxfam strategy aimed at redistributing the heavy and unequal care of women and girls in selected districts in Zimbabwe through a focus on gendered social norms. WE-Care's programmatic work aims to identify those norms which appear to be most malleable and activities that appear to have the greatest potential to promote positive change, as well as identifying sensitive issues, drawing on the rich information that the FGDs elicited. Here, we make some preliminary proposals drawing on this material.

The WE-Care programme in Zimbabwe has identified the following key allies in the strategy: newlyweds, elderly men, female leaders, young people and school pupils. It has also identified a number of partners to support outreach to these groups, including community-based organizations, women's rights organizations, media, print and electronic outlets, elderly women (in their role as gatekeepers), religious leaders, relevant government ministries, the Chiefs' Council, the Parliamentary Portfolio Committees and the Gender Commission. This list of partners resonates well with those individuals that communities identified as the most trusted messengers.

\section{Where to start?}

The gendered norms that appear to be more malleable are those that are being directly challenged by the country's economic crisis and the behavioural changes it has prompted. A key example is the expectation that men fulfil the role of household provider through productive work and women fulfil roles in domestic work. As discussed above, owing to economic crisis, fewer men are in formal employment while more women are engaging in productive activity, particularly in cross-border trade and informal vending. This means that women are increasingly taking on a breadwinning role, while there was some evidence of men in these households taking on some care-related chores. This tension between changes in behaviour and the underlying norm could be a possible lever for change, not least as such households are widespread. 


\section{Integrating information from the FGDs}

WE-Care in Zimbabwe has proposed various types of activities that might contribute to shifting perceptions around UCDW, to include community dialogues, the training and capacity building of care champions, work with youth to support their role as change agents, awareness raising (through community events, road shows, media messaging) and work with potential influencers and role models such as Members of Parliament and celebrities.

The FGD findings point to four objectives that WE-Care programming could seek to fulfil, and suggest some specific activities that could potentially contribute to their fulfilment:

\section{- Reframing traditional understandings of the work that women and men do}

- Reframe notions of what constitutes 'respectable' work for women. The role of 'good' women was often expressed in terms of respectability and dignity (see, for example, the sayings Mukadzi chaiye haazorori: $A$ respectable woman does not rest, she is always working [01], Mushamukadzi: A respectable household is underpinned by a woman [K24]). It may be desirable to affirm and extend this notion of respectability in the context of women who are taking on increased productive activity and doing less care work. Such a framing would highlight that this income generation is compatible not only with women's continued identity as pillars of the home but also with increased male involvement in UCDW. In other words, it would extend perceptions of respectability to encompass those women who are engaged in paid work and whose husbands participate in care work.

- Reframe understandings of men as providers. Related to the point above, the care work that men undertake could be framed as a different form of 'provision' for their families, as this notion of men as providers is resonant (for example, Ava ndivachibhiribhidhe: This is a busy man, a man who is always busy working to provide for his family [K20], Mukadzi kana murume chaiye chaiye anochengeta mhuri yake: $A$ good man will provide for his family's needs [01]). Such positive sayings could be invoked in relation to family men who are involved in both productive work and care work.

- Use traditional sayings to illustrate new roles. For example, traditional sayings focused on the importance of training children from young age (e.g. Umthwentwe uhlaba usamila: One (a child, whether male or female) has to be groomed at a tender age [B11, B15]) could be accompanied by a 'discordant' image such as a boy following his mother around as she undertakes care work, or a girl following her father as he plants crops.

\section{- Challenging commonly held perceptions of the roles of women and men}

- Hold community dialogues with women-only groups, so that they come to view men's involvement in UCDW more positively - as something to champion rather than to ridicule. The contrast could be drawn, for example, between a woman who mocks male involvement in UCDW but goes home to cook, do laundry etc., and a family in which care work is shared and family members spend time together happily. These dialogues would aim to change the perceptions of some women that male involvement in care work constitutes an invasion of 'their' space and could involve aspects such as role-playing around negotiating male entry into the kitchen.

\section{- Challenge perceptions of 'light' and 'heavy' work. It} emerged in the focus groups that the work that women do (or should do) is 'light' - including most forms of household work - while the role of men is to undertake 'heavy' work. These caricatures serve to reinforce a gendered division of labour, but they do not fit with the reality of the work that women and men do. Bringing this mismatch to light could serve to change perceptions. For example, communication materials could serve to affirm agricultural lor other productive workl as 'heavy' but also be clear that many forms of care work are equally taxing. Conversely, advocates could contrast the image of 'light' activities with the reality that many care tasks such as washing clothes and carrying children are demanding. Another opportunity may be to emphasize the time it takes to do supposedly 'light' activities - making it clear that these are in fact demanding activities that are worthy of being respected and shared.

\section{- Challenge perceptions of 'skill' and of 'value'. The FGD} findings point to widespread perceptions that care work, usually done by women, requires few skills; this suggests an opportunity for advocacy material to make clear how much time and effort is required to learn to do care-related activities well, and to shift perceptions of what constitutes training and skill acquisition to extend beyond formal methods of learning.

\section{- Highlighting the positive aspects of shared care work and adverse effects that present care loads have for women}

\section{- Portray positive aspects of shared care work. FGD} participants were very clear on the potentially positive effects of greater male involvement in care work, not only for women but for family harmony and unity. Campaigns could build upon this notion, making it clear that men who participate in care work are not foolish or bewitched; rather they are strong men who are willing to deviate from existing attitudes and patterns of behaviour. Such men could be shown as progressive and aspirational.

\section{- Build upon female recognition of negative effects of} overwork. Women particularly recognized a slew of ill effects resulting from over-exertion in care-related work - notably health effects such as ageing too quickly and illness. Depicting the toll that this involvement in heavy and unequal care takes on women could be used to advocate for greater investments (by families, communities and other actors) in labour-saving equipment. Likewise, such a campaign could also provide an opportunity to affirm that 'resting together' brings greater family happiness and the goal should be team work - addressing the norm that 'good' women should always be working. 


\section{- Emphasizing existing male involvement in care and seeking to extend this}

\section{- Start with existing male involvement in care. An} appropriate starting point might be those tasks that men are already undertaking in some areas - e.g. water and fuel collection in areas where these are scarce resources - as these are perceived as more socially acceptable and less degrading, especially where they involve the use of equipment like scotch carts. This approach might also focus on those household chores that are perceived as relatively more acceptable, such as preparing meals, as opposed to changing nappies or bathing children, activities which are considered 'sensitive'.

- Make more visible the 'hidden' work of men. Activities could be designed to bring into the open the hidden work that men are already doing, according to the FGDs, and thereby help to render it more acceptable. For example, this could be done:
- In a humorous way through community theatre.

- Through regular community events such as competitions in laundry, cooking and other care-related activities. Advance preparation may be needed - e.g. men may require training in activities like cooking. The facilitators could be well known to the community - for example, celebrity chefs.

- By setting aside specific days each week when community leaders and men do tasks that are not degrading and in keeping with local perceptions of masculinity. This could involve men gathering water and firewood using equipment such as a wheelbarrow.

- Expand male involvement in care into new areas. To shift community expectations further, structured activities could be designed that seek to extend male involvement in care - e.g. men doing cleaning or care tasks with boys at a local school. Such days could be designated by public declarations, to foster participation and shifts in expectations. ${ }^{16}$ Such activities would need to be underpinned by careful planning and follow-up to reinforce new norms.

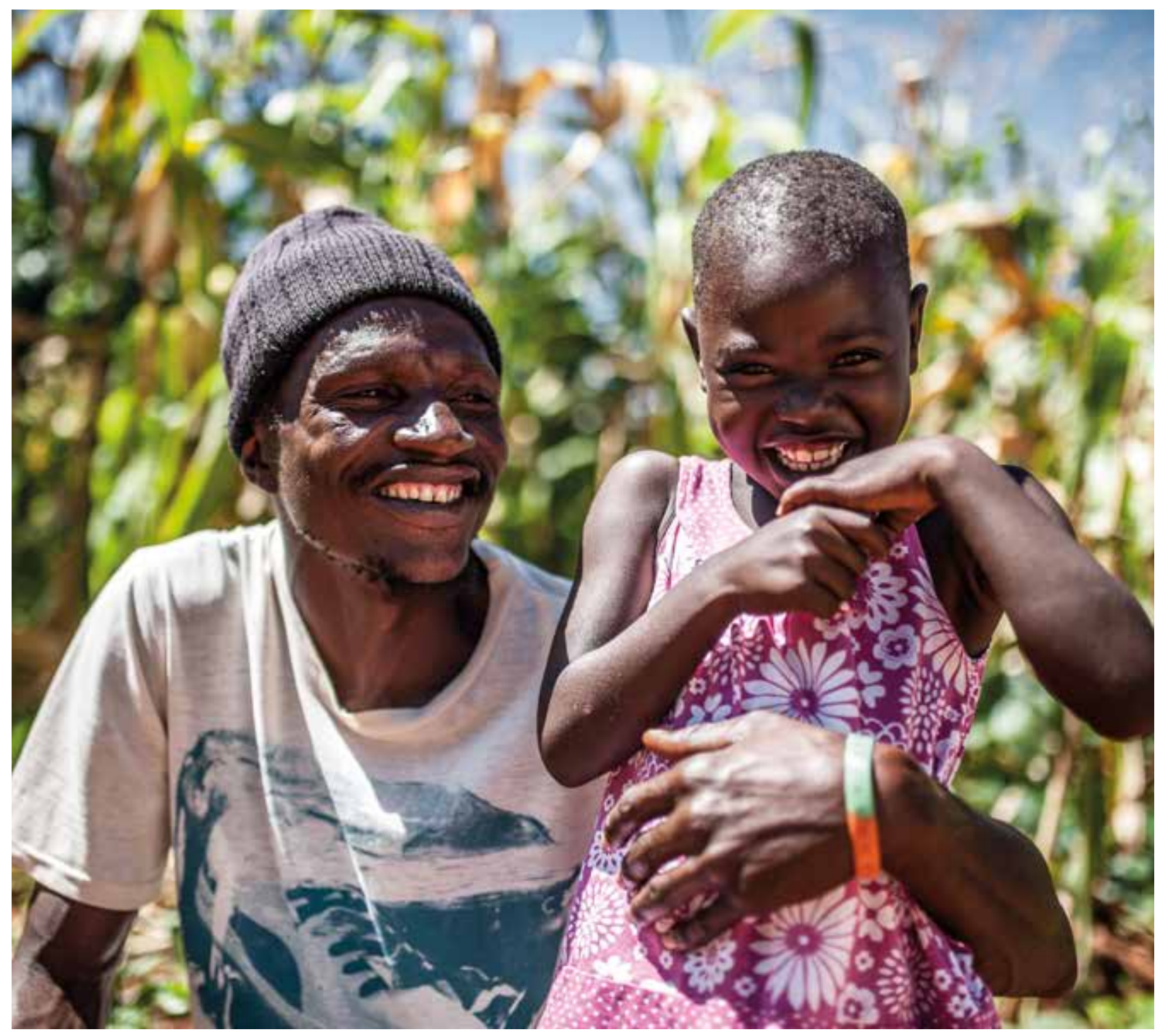




\section{CONCLUSIONS}

This report has focused on gendered norms underlying the division of labour in selected communities of rural Zimbabwe and has sought to ascertain to what extent these may be pliable and subject to change. The first part focused on shared understandings governing the division of productive and reproductive activity among men and women, and boys and girls. It revealed a general expectation that women are responsible for all household chores, and that children particularly girls - also participate actively in many activities, suggesting that norms around age are also influential. Women also engage in income-generating and productive work, though they often felt that this contribution was not recognized, or was sometimes hidden to avoid disapproval from others. In turn, men are assigned the role of family providers - with perceptions of whether men are providing financially for their family appearing to influence how their engagement in unpaid care is regarded. It is more acceptable if they are the primary breadwinner than if they are not Iwords like 'lazy' and 'incompetent' were used to describe men who engaged only in household chores).

The discussions showed that men were rarely reported to engage in UCDW in the selected communities. Their involvement in care work was generally viewed as unnatural by men and women alike (with the recurring use of the words 'bewitched' and 'love potion' signifying a recourse to supernatural forces to explain this transgression). Penalties for such engagement were evident - men taking on care work were subject to ridicule, whereas some women perceived that male engagement in care threatened their own identity as caregivers. Participants universally had unforgiving views towards women who did not engage in care work - such women were described as outcasts who deserved criticism and censure - potentially including divorce - and in the case of girls, the threat of violence.

The types of work which the FGDs identified as most acceptable for men attest to the strength of norms underlying the male role but also suggest where strategies aimed at change could focus. Specifically, participants believed that care work was more acceptable for men if it could be done behind closed doors, or if it required equipment, in part because the use of equipment made it less visible. For example, fetching water on foot was considered much less acceptable for men than fetching it using a scotch cart. Acceptable income-generating activities for women involved activities that were 'not too heavy', that could be combined with UCDW, and that aligned with traditional women's roles le.g. doing laundry for other households, as opposed to carpentry).

Both cultural expectations and biological differences featured prominently in participants' explanations of the distribution of work. The distinctions participants made were also reflected in discussions of 'economic norms' - where there was a tendency to argue that activities traditionally carried out by women and girls involved less skill and were less valuable than those typically conducted by men and boys. An exception was childcare, which was widely viewed as important.

However, participants also pointed to some unravelling of traditional norms with respect to the gendered division of labour. Moreover, economic crisis was prompting a change in the division of work, although in some cases norms were slow to adapt, causing tensions. Migration appeared to be more acceptable for men than for women. Participants described the need for women to take on additional productive and income-generating work, amid widespread male unemployment. This appeared to be linked to women's desire for greater male involvement in unpaid care and had prompted more men to engage in UCDW, although often this took place in private and was described as 'emasculating'. There was some evidence of temporary male involvement in care - for instance, in cases of women's sickness, pregnancy or after childbirth - and that this was becoming more widespread, hinting at processes of longer-term change.

The discussions also revealed some desire for change, particularly amongst women and younger men. This was described in part as a response to the economic realities in the country - which notably had resulted in increased female involvement in paid work - but it also encountered some resistance.

Female participants pointed to a host of negative consequences of the unpaid care workloads of women and girls. For girls, the main consequence was falling behind on school work or dropping out of school. For women, health implications were cited most frequently l'getting old too quickly', tiredness and aches, being prone to illness) but participants also expressed concerns over the impact on family life, women's psychological wellbeing and a lack of time to pursue income generation. Participants, notably women and younger men, articulated in specific terms what a more equitable distribution of labour could look like. In several FGDs, they expressed a desire that young people in the community would experience a more equitable distribution of work when they formed their own families.

The FGDs prompted discussion that could inform specific strategies focused on change. Participants identified trusted messengers - emphasizing the role of traditional leaders, religious leaders, village workers and local politicians, though they also observed that role models were in short supply, both in their communities and in the media. They outlined the most effective ways of communicating information, particularly for youth, and highlighted several channels, notably community theatre, bulk SMS, public meetings, road shows and radio programmes - with the latter particularly salient for older people. Social media was not universally trusted but was considered important for reaching youth. 
In terms of specific support needed to foster the more equitable sharing of work, participants focused on the need for parents to treat boys and girls equally, to ensure boys were equipped to carry out UCDW, and to encourage girls to reach their full potential. For the latter, they recognized the need for reinforcement from teachers and others in the community. For men, concrete needs identified by participants included training from a very early age, a platform to identify like-minded men, and peer support. The discussions also pointed to female complicity in the persistence of norms that circumscribe the gendered division of labour. This suggests a need for awareness raising among women so that they do not regard greater male involvement in UCDW as degrading or as constituting an invasion of their personal domain.
Finally, the report has proposed some preliminary implications stemming from this research. It suggests that the most malleable norms may be those being directly challenged by the country's economic crisis and the behavioural changes it has prompted - and outlines several potential objectives of future activity, including a reframing of the traditional roles assigned to women and to men; challenging women's perceptions of male involvement in care, as well as community perceptions of what constitutes light and heavy work, and skills and value; highlighting positive aspects of shared care work and adverse effects of the present care workload for women; and emphasizing existing male involvement in care and seeking to extend this into new areas. A number of specific activities are proposed.

\section{ANNEX 1 - FOCUS GROUP SCRIPT}




\section{ANNEX 2 - PROFILES OF THE FGD DISTRICTS}

This annex provides a socio-economic profile of the districts of Zimbabwe in which the focus groups were conducted. Data is from the 2012 census compiled by UNICEF: https://www. unicef.org/zimbabwe/National_Census_ Results_2012fnl30-12.pdf.

\section{- Bubi district, Ward 11 and Ward 15}

- Gold mining (and environmental impacts) - reports show that mining has destroyed the environment, left cattle without grazing land and exposed residents to health hazards. - District is $98 \%$ rural, under-five mortality rate (U5MR) of 73 , primary school net attendance of $85 \%$, secondary school $36 \%$ (placing it in lowest quintile among Zimbabwe's districts for this indicator), $32 \%$ have access to sanitation lagain placing it in lowest quintile), $21 \%$ have access to electricity, $89 \%$ have fuel for cooking, $78 \%$ can access safe drinking water.

\section{- Gutu district, Ward 9}

- District is $96 \%$ rural, U5MR of 79 , primary school net attendance is $90 \%$, secondary is $56 \%, 52 \%$ have access to safe sanitation, just $9 \%$ to electricity (placing it in lowest quintile among Zimbabwe's districts for this indicator), 94\% to fuel for cooking and $60 \%$ have access to safe drinking water.

\section{- Masvingo district, Ward 20 and Ward 24}

- District is $97 \%$ rural with U5MR of 76, primary school net attendance of $87 \%$, secondary school $52 \%, 39 \%$ access to safe sanitation, $20 \%$ access to electricity, $89 \%$ access to fuel for cooking and $58 \%$ access to safe drinking water (placing it in lowest quintile among Zimbabwe's districts for this indicator).

\section{- Seke district, Ward 10}

- District is $96 \%$ rural, U5MR 86 , primary school net attendance $88 \%$, secondary school $58 \%, 50 \%$ have access to safe sanitation, $39 \%$ access to electricity, $80 \%$ have fuel for cooking and $77 \%$ access to safe drinking water.

\section{FIGURE A.1 PROFILE OF SELECTED DISTRICTS IN ZIMBABWE AND NATIONAL AVERAGES}

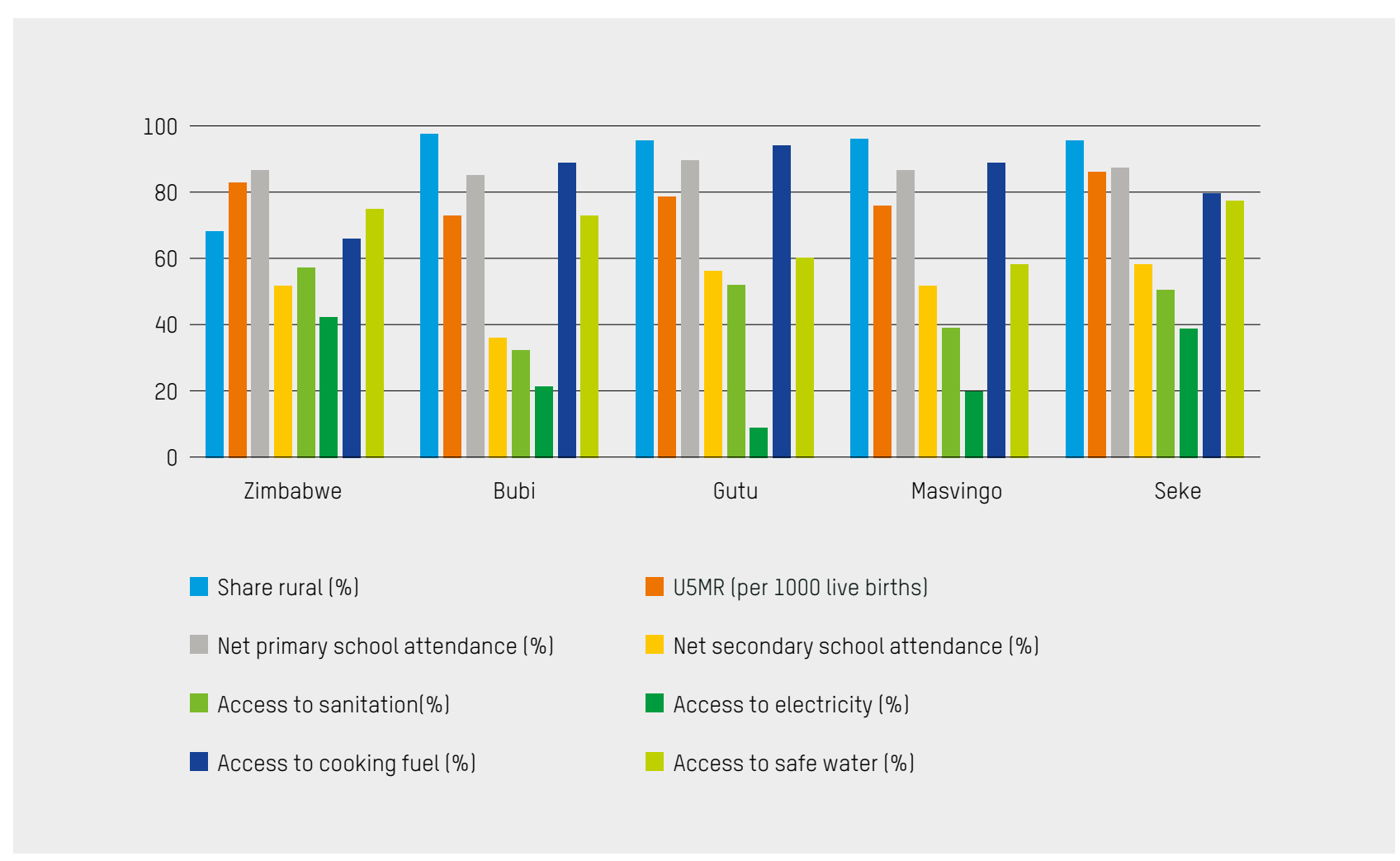




\section{ANNEX 3 - INFORMATION ABOUT FOCUS GROUP PARTICIPANTS}

TABLE A.1 NUMBER, COMPOSITION AND LOCATION OF FOCUS GROUPS

\begin{tabular}{|c|c|c|c|c|c|c|c|c|}
\hline Location & $\begin{array}{l}\text { District/ } \\
\text { ward }\end{array}$ & Code & Composition & Age (years) & $\begin{array}{l}\text { Marital } \\
\text { status }\end{array}$ & Education & Paid activity & $\begin{array}{l}\text { Household } \\
\text { size }\end{array}$ \\
\hline $\begin{array}{l}\text { Bekezela } \\
\text { shopping } \\
\text { centre }\end{array}$ & $\begin{array}{l}\text { Bubi } \\
\text { district, } \\
\text { Ward } 11\end{array}$ & $\mathrm{~B} 11$ & 8 Females & $\begin{array}{l}\text { 34-62, } \\
\text { median: } 56\end{array}$ & $\begin{array}{l}6 \text { married, } 2 \\
\text { widowed }\end{array}$ & $\begin{array}{l}4 \text { primary, } 4 \\
\text { some high } \\
\text { school }\end{array}$ & $\begin{array}{l}5 \text { had paid work: } 3 \\
\text { vendors, } 1 \text { piece- } \\
\text { worker, } 1 \text { health } \\
\text { worker. All short-term } \\
\text { duration except } 1 \\
\text { vendor }\end{array}$ & $\begin{array}{l}\text { 3-8, } \\
\text { median: } 6\end{array}$ \\
\hline $\begin{array}{l}\text { Bekezela } \\
\text { shopping } \\
\text { centre }\end{array}$ & $\begin{array}{l}\text { Bubi } \\
\text { district, } \\
\text { Ward } 15\end{array}$ & $\mathrm{~B} 15$ & $\begin{array}{l}11 \text { (4 Males, } \\
7 \text { Females) }\end{array}$ & $\begin{array}{l}\text { 18-68, } \\
\text { median: } 56\end{array}$ & $\begin{array}{l}5 \text { married, } 3 \\
\text { widowed, } 1 \\
\text { divorced, } 2 \\
\text { never } \\
\text { married }\end{array}$ & $\begin{array}{l}8 \text { primary, } 3 \\
\text { some high } \\
\text { school }\end{array}$ & $\begin{array}{l}9 \text { had paid work (all } \\
\text { men, } 5 \text { women) - all } \\
\text { different activities; } \\
\text { majority (5) short- } \\
\text { term }\end{array}$ & $\begin{array}{l}\text { 5-13, } \\
\text { median: } 6\end{array}$ \\
\hline $\begin{array}{l}\text { Gilston } \\
\text { Farm }\end{array}$ & $\begin{array}{l}\text { Seke } \\
\text { district, } \\
\text { Ward } 10\end{array}$ & G10 & $\begin{array}{l}16 \text { (7 Males, } \\
9 \text { Females) }\end{array}$ & $\begin{array}{l}\text { 34-72, } \\
\text { median: } 45\end{array}$ & $\begin{array}{l}9 \text { married, } 2 \\
\text { widowed, } 4 \\
\text { divorced, } 1 \\
\text { never } \\
\text { married }\end{array}$ & \begin{tabular}{|l|}
3 primary, \\
12 some \\
high \\
school, 1 \\
high school
\end{tabular} & $\begin{array}{l}6 \text { had paid work, } 5 \\
\text { farmers, } 1 \text { ward } \\
\text { coordinator }\end{array}$ & $\begin{array}{l}\text { 2-13, } \\
\text { median: } 6\end{array}$ \\
\hline $\begin{array}{l}\text { Kunzwana } \\
\text { Women's } \\
\text { Associa- } \\
\text { tion }\end{array}$ & $\begin{array}{l}\text { Masvingo } \\
\text { district, } \\
\text { Ward } 20\end{array}$ & K20 & $\begin{array}{l}12 \text { (5 Males, } \\
7 \text { Females) }\end{array}$ & $\begin{array}{l}21-65 \\
\text { median: } \\
43.5\end{array}$ & $\begin{array}{l}7 \text { married, } 1 \\
\text { widowed, } 2 \\
\text { divorced, } 2 \\
\text { never } \\
\text { married }\end{array}$ & $\begin{array}{l}1 \text { none, } 5 \\
\text { primary, } 6 \\
\text { some high } \\
\text { school }\end{array}$ & $\begin{array}{l}4 \text { in paid work, } 3 \\
\text { farmers }\end{array}$ & $\begin{array}{l}\text { 2-8, } \\
\text { median: } 5\end{array}$ \\
\hline $\begin{array}{l}\text { Kunzwana } \\
\text { Women's } \\
\text { Associa- } \\
\text { tion }\end{array}$ & $\begin{array}{l}\text { Masvingo } \\
\text { district, } \\
\text { Ward } 24\end{array}$ & K24 & 8 Females* & $\begin{array}{l}\text { 26-53, } \\
\text { median: } 42\end{array}$ & $\begin{array}{l}6 \text { married, } 1 \\
\text { divorced }\end{array}$ & $\begin{array}{l}3 \text { primary, } 4 \\
\text { some high } \\
\text { school }\end{array}$ & $\begin{array}{l}1 \text { in paid work as } \\
\text { short-term village } \\
\text { health worker }\end{array}$ & $\begin{array}{l}\text { 5-8, } \\
\text { median: } 6\end{array}$ \\
\hline $\begin{array}{l}\text { Kunzwana } \\
\text { Women's } \\
\text { Associa- } \\
\text { tion }\end{array}$ & $\begin{array}{l}\text { Gutu } \\
\text { district, } \\
\text { Ward } 9\end{array}$ & K9 & 14 Females & $\begin{array}{l}\text { 30-70, } \\
\text { median: } 43\end{array}$ & $\begin{array}{l}9 \text { married, } 2 \\
\text { widowed, } 2 \\
\text { divorced, } 1 \\
\text { never } \\
\text { married }\end{array}$ & $\begin{array}{l}1 \text { none, } 4 \\
\text { primary, } 9 \\
\text { some high } \\
\text { school }\end{array}$ & $\begin{array}{l}8 \text { in paid work: } 4 \\
\text { garden farming, } 2 \\
\text { vending (1 seasonal, } \\
1 \text { short-term), 1 } \\
\text { selling farm produce, } \\
1 \text { in poultry (long- } \\
\text { term) }\end{array}$ & $\begin{array}{l}\text { 2-8, } \\
\text { median: } 4\end{array}$ \\
\hline
\end{tabular}

* Note: Information is missing for one Female participant for Ward 24 , so the remaining data refers to the 7 for whom this information is available. 


\section{ANNEX 4 - RANKINGS USED IN THE EXERCISE ON 'ECONOMIC NORMS'}

TABLE A.2 SUMMARY OF RANKING OF TASKS REQUIRING MOST AND LEAST SKILL

\begin{tabular}{|l|l|l|l|l|l|l|l|}
\hline Most skill required & B11 & B15 & 01 & K9 & K20 & K24 & $\begin{array}{l}\text { No. of } \\
\text { mentions }\end{array}$ \\
\hline House construction/repairs & 1 & 1 & 1 & & 3 & 2 & 5 \\
\hline Planting/harvesting & 2 & & & 2 & & 1 & 3 \\
\hline Care for elderly, ill, disabled & 3 & & & & 1 & 3 & 3 \\
\hline Taking care of farm animals & & & & 3 & 2 & & 2 \\
\hline Carpentry/making furniture & & 2 & & & & & 1 \\
\hline Drying/processing agricultural products & & 3 & & & & & 1 \\
\hline Caring for children & & & & 1 & & \\
\hline
\end{tabular}

\begin{tabular}{|l|l|l|l|l|l|l|l|}
\hline Least skill required & B11 & B15 & 01 & K9 & K20 & K24 & $\begin{array}{l}\text { No. of } \\
\text { mentions }\end{array}$ \\
\hline Cleaning house or compound & 1 & 3 & 3 & 1 & 1 & 5 \\
\hline Fuel or water collection & 3 & & 2 & 2 & 2 & & 4 \\
\hline Meal preparation & & & 1 & & 3 & & 1 \\
\hline Drying/processing agricultural products & & & & & & 2 \\
\hline Washing, ironing, mending clothes & 2 & & & & & & 1 \\
\hline Taking care of farm animals & & 1 & & & 3 & & 1 \\
\hline Planting/harvesting & & 2 & & & & 2 \\
\hline Caring for children & & & & & & & 1 \\
\hline Carpentry & & & & & \\
\hline
\end{tabular}

Note: Tasks in bold were agreed to by at least two-thirds (4 in 6) of the focus groups. Tasks in yellow are care-related. Red text indicates female-only focus groups. 


\section{ANNEX 4 - RANKINGS USED IN THE EXERCISE ON 'ECONOMIC NORMS' (continued)}

\section{TABLE A. 3 SUMMARY OF RANKINGS OF TASKS TO WHICH PARTICIPANTS ASSIGNED MOST}

\section{AND LEAST VALUE}

\begin{tabular}{|l|l|l|l|l|l|l|l|}
\hline Most value attributed & B11 & B15 & 01 & K9 & K20 & K24 & $\begin{array}{l}\text { No. of } \\
\text { mentions }\end{array}$ \\
\hline Planting/harvesting & 1 & & 2 & 2 & 1 & 1 & 5 \\
\hline Caring for children & 3 & 2 & 3 & & & 3 & 4 \\
\hline Meal preparation & 2 & & & 3 & & 2 & 3 \\
\hline Fuel or water collection & & 3 & & 1 & 2 & & 3 \\
\hline Drying/processing agricultural products & & 1 & & & & & 1 \\
\hline House construction/repairs & & & 1 & & & & 1 \\
\hline Selling products/trading & & & & & 3 & & 1 \\
\hline
\end{tabular}

\begin{tabular}{|l|l|l|l|l|l|l|l|}
\hline Least value attributed & B11 & B15 & 01 & K9 & K20 & K24 & $\begin{array}{l}\text { No. of } \\
\text { mentions }\end{array}$ \\
\hline Carpentry & 1 & & 1 & 1 & 1 & 2 & 5 \\
\hline Selling products/trading & 3 & 1 & & 3 & & 1 & 4 \\
\hline Drying/processing agricultural products & 2 & & 2 & & & & 2 \\
\hline Washing, ironing, mending clothes & & 3 & & & 2 & & 2 \\
\hline House construction/repairs & & & 2 & & & & 3 \\
\hline Taking care of farm animals & & & 3 & & & & 1 \\
\hline Care for elderly, ill, disabled & & & & & 3 & & 1 \\
\hline Meal preparation & & & & & & 4 \\
\hline Cleaning house/compound & & & & & 1 \\
\hline
\end{tabular}

Note: Tasks in bold were agreed to by at least two-thirds ( 4 in 6 ) of the focus groups. Tasks in yellow are care-related. Red text indicates female-only focus groups. 


\section{ANNEX 5 - TASKS RANKED BY PERCEIVED ACCEPTABILITY FOR MEN AND FOR WOMEN IN SELECTED FGDS*}

\begin{tabular}{|c|c|c|}
\hline & Men (reproductive tasks) & Women (productive tasks) \\
\hline 01 & $\begin{array}{l}\text { Cooking } \\
\text { Ironing clothes } \\
\text { Planting flowers } \\
\text { Bathing wife if she is sick } \\
\text { Changing nappies } \\
\text { Washing adult nappies (for adults who are ill) } \\
\text { Bathing children } \\
\text { Doing the dishes }\end{array}$ & $\begin{array}{l}\text { Farming } \\
\text { Running poultry project } \\
\text { Providing casual labour for a fee } \\
\text { Cutting grass for thatching } \\
\text { Repairing traditional pole and dagga huts using mud } \\
\text { Building toilets } \\
\text { Thatching family huts (suggestion women afraid of } \\
\text { heights) }\end{array}$ \\
\hline B15 & $\begin{array}{l}\text { Fetching firewood } \\
\text { Fetching water } \\
\text { Cooking } \\
\text { Taking care of the elderly and sick } \\
\text { Sweeping/cleaning house } \\
\text { Laundry/ironing clothes } \\
\text { Bathing children }\end{array}$ & $\begin{array}{l}\text { Farming } \\
\text { Working for local district council } \\
\text { Working at mine } \\
\text { Building/construction work } \\
\text { Brick moulding } \\
\text { Gold panning } \\
\text { Selling wood carvings and farm produce } \\
\text { Carving }\end{array}$ \\
\hline K9 & $\begin{array}{l}\text { Looking after farm animals } \\
\text { Taking care of children } \\
\text { Fetching water } \\
\text { Fetching firewood } \\
\text { Cooking } \\
\text { Laundry and ironing } \\
\text { Bathing children } \\
\text { Doing the dishes } \\
\text { Sweeping and cleaning the house }\end{array}$ & $\begin{array}{l}\text { Buying and selling } \\
\text { Providing casual labour on farms } \\
\text { Farming on a commercial basis (not subsistence } \\
\text { farming) } \\
\text { Brick moulding } \\
\text { Selling small and large livestock } \\
\text { Cutting and making poles for fencing purposes } \\
\text { Building/construction work } \\
\text { Carving }\end{array}$ \\
\hline K24 & $\begin{array}{l}\text { Cooking } \\
\text { Fetching firewood } \\
\text { Laundry } \\
\text { Taking care of the sick } \\
\text { Doing dishes } \\
\text { Sweeping and cleaning the house }\end{array}$ & $\begin{array}{l}\text { Farming } \\
\text { Looking after farm animals } \\
\text { Cattle herding } \\
\text { Fetching firewood } \\
\text { Carving }\end{array}$ \\
\hline
\end{tabular}

*Note: Information not available for Bubi 11 or Masvingo 20. For 01, tasks in italics are deemed unacceptable; those not in italics are deemed acceptable. 


\section{ANNEX 6 - FULL LIST OF SAYINGS THAT EMERGED AROUND THE DIVISION OF WORK}

\section{Children}

Isigogo sigoqwa sisemanzi: One has to be groomed/trained at a tender age [B11, B15]

Umthwentwe uhlaba usamila: One (a child, male or female) has to be groomed at a tender age [B11, B15]

Udiyo lufuze imbiza (abantwana): Like mother like daughter or like father like son [B11, B15]

Inyathi ibuzwa kwabaphambili: There is wisdom beyond grey hair [B11, B15]

Ukuzala yikuzimbela: Having children is helpful, as they are going to assist you when they grow up [B11, B15]

Inyoni itshayelwa abadala: Whatever you do as a child, the success is rendered to the parents [B11]

\section{What 'good women' do}

Good women are hard-working, dignified, well-respected and 'like a granary, save resources' [B15]

Mukadzi chaiye haazorori: $A$ respectable woman does not rest, she is always working [01]

Mukadzi chaiye haasiye murume wake achiita basa repamba: A respectable woman does not let or allow a man to do care and domestic work [01]

Mukadzi chaiye chaiye anoshanda mabasa ese epamba: A respectable and good woman does care and domestic work and any other task around the homestead [01]

Mukadzi chaiye chaiye anoona kuti mhuri yake yakachengetedzeka - kubva kuna baba nevana: A good women ensures that her whole family from children to the spouse are well looked after and are secure [01]

Umama oqotho ubonakala ngokwenza imisebenzi yangekhaya: For one to be called a good woman, she should be hard working [B11]

Mushamukadzi: A respectable household is underpinned by a woman [K24]

Mukadzi uyu murume chaiye: This woman is a real man [K9, K20, K24]

Uyu mukadzi mudealer/gweja [contemporary]: This woman is a dealer/hustler [K9]

Mukadzi uyu igweja chairo: This woman is a hustler [K20, K9]

Uyu mukadzi mudealer chitaurwa chiononyanya kushanda muno muward nekuti mazuvano madzimai arikuwanikwa achiita zvekutengesa huye vana vedu vechidoko ndizvo zvavanonyanyotaura: This woman is a dealer/hustler [K9]

Note: see page 17 on the connotations of the word 'hustling' in relation to 'good women'

\section{What 'good women' do not do}

Ava ndiva Hlezu chaivo: This woman is a wayward woman [K20]

Ava ndiva macharika: This woman is not stable, is in a brittle relationship, is not marriageable [K20]

Uyu makadzi inyapura chaiyo: She is a very lazy woman [K24]

\section{What 'good men' do}

Murume chaiye anochengeta mhuri yake: $A$ well organized man will provide for all his family's needs [01]

Ava ndiva chibhiribhidhe: This is a busy man, a man who is always busy working to provide for his family [K20]

Murume uyu ane musoro: This is a smart man, who is sharp [K9, K20, K24]

Murume uyu akarongeka: This man is organized and runs family affairs in a responsible manner [K9, K20]

Uyu murume ibango remusha: This man is pillar of his house [K9]

\section{What 'good men' do not do}

Uyu murume isimbe chaiyo: This man is a really lazy man [K24]

Murume uyu haana musoro: This man is not smart [K9, K20, K24]

Uyu murume ivhiri redanda: This is a totally useless man [K20]

Murume chaiye haapedzi mari yese kubhawa: An organized and responsible man does not spend all money on beer drinking [01] 


\section{ANNEX 6 - FULL LIST OF SAYINGS THAT EMERGED AROUND THE DIVISION OF WORK (continued)}

\section{Ageing}

Udwayi ufa lensiba zakhe (both): Virtue is not lost with age [B11]

Gugasithebe kade wacholela (mama): Advice to someone who has been a useful member of the family, to hand over the button to the young ones [B11]

\section{Other}

Umzenzi kakhalelwa kukhalelwa umenziwa: You can't sympathize with someone who does not want to be advised [B11] Isala kutshelwa sibona ngomopho: If you do not take advice it may lead to the wrong path [B15]

Hamba juba bazakucutha phambili: If you do not take advice it may lead to the wrong path ${ }^{17}$ [B15]

Udwayi ufa lensiba zakhe: It is difficult to change someone's attitude or behaviour [B15]

Ngamathe lolimi: They are inseparable [B15]

Izolo bekukade kungenje: Things have changed over time [B11]

Akukhulunyelwa emasekweni: Confidential issues should be discussed in private [B11]

Savela sakuthola kunjalo, akuntshintsheki, ngamasiko ethu: One cannot shift our traditions and culture [B11]

Induku enhle iganyulwa ezizweni: A good woman is hard to find [B1l] 


\section{ANNEX 7 - REFLECTIONS ON THE METHODOLOGY}

\section{Feedback on the focus groups from facilitators and participants}

Both facilitators and participants gave positive feedback. Facilitators reported that the discussions went well and were easy to manage $[\mathrm{B} 11, \mathrm{~B} 15, \mathrm{~K} 1, \mathrm{~K} 20, \mathrm{~K} 24,01]$, and that the participants were engaged and comfortable sharing their views [B11, B15, $\mathrm{K} 1, \mathrm{~K} 20, \mathrm{~K} 24]$. Along similar lines, participants reported that they appreciated the process and content of the discussions $[\mathrm{B} 15,01, \mathrm{~K} 1, \mathrm{~K} 20, \mathrm{~K} 24]$. They found that they generated healthy debate that they had not had previously [01, K20] and made them think deeply around the day-to-day issues that they faced [K9]. They did not make any specific suggestions for changes to the process [B11, B15, K9, K20, K24, 01].

Length of the FGDs. Two facilitators reported that the process took too much time [B11, B15]. They said that towards the end, some participants lost concentration and/or withdrew [B11, B15]. In one group, the facilitator felt that more time was needed for all the exercises [01]. The suggestion was made to cut the discussion from four hours to two hours [B11]. Note that this issue also surfaced in the pilots, and was discussed during the planning of the FGDs, but it proved difficult to agree on any areas to cut - this discussion should be revisited if the tool is used in the future.

\section{Additional comments}

Participant recruitment. There were relatively few male participants in the FGDs 133\% overall, 41\% in the mixed-sex discussions); however, this may be unavoidable in the selected communities owing to the migration of younger men. It may be worth considering whether different modalities might bolster male participation - e.g. holding the focus groups at different times of day, in different seasons, or restricting the length to an hour - or whether it might make sense to use different instruments with one or a small group of men, such as semi-structured interviews, to elicit their perspectives.

Discussion of WE-Care in focus groups. Some participants in the focus groups were invited because they had previously participated in WE-Care activities. Moreover, in one FGD [K9], the report notes that the participants discussed the FGD in relation to previous activities under WE-Care, such as RCA and community dialogues, while reports from four of the other FGDs referenced the WE-Care programme [B11, B15 K20 and K24]. While situating the FGDs in these wards and including the programme in the discussion may have encouraged the participation of some community members and rendered them familiar with the issues at hand, it also means that their perceptions may not be representative of the broader community. Some reports indicate that the FGDs began with an overview of the WE-Care initiative - it would be advisable not to include this so early in the discussions because of the risk of biasing the subsequent discussion.

Revising the FGD instrument. Section 1 on the household division of labour and section 4 on the acceptability of men taking on care work and women taking on productive/income-generating activity seemed to elicit particularly lively discussion, with discussion in the first section foreshadowing many issues that would be discussed at greater length in subsequent exercises. Some questions in section 4 and in section 5 (on change over time) elicited similar answers, suggesting scope for integrating these two sections and reducing the total number of questions. However, this would be insufficient to reduce the overall script to a manageable length; further cuts will be needed.

Reporting on the FGDs. Some issues also emerged with the reporting on the FGDs, with identical text appearing in more than one report. While it is likely that different groups engaged in very similar discussions, it would be advisable for documenters to be as specific as possible in recording the content. 


\section{REFERENCES}

1 G. Mackie, F. Moneti, H. Shakya and E. Denny (2015) What are social norms? How are they measured? NYC: UNICEF, p. 4.

2 http://indicators.report/targets/5-4/

3 Align (Advancing Learning and Innovation on Gender Norms): https://www.alignplatform.org/norms

${ }^{4}$ Mackie et al. (2015) op. cit.

5 Ibid.

6 R. Marcus and C. Harper (2015) How do Gender Norms Change? Research and Practice Note. London: ODI.

7 Mackie et al. (2015) op. cit., p.4

${ }^{8}$ L. Heise, (2013) 'Social norms. Introduction'. Presentation at the Expert Workshop on Empowering Adolescent Girls, 26 April, London.

9 H.M. Apila, H.R. Gimbo, C.B. Kodili and J. Rosdahl (2011) Recognise, redistribute, reduce the women's unpaid care burden: Women and the work they do for nothing, Kampala: ActionAid Uganda; T. Kidder, Z. Mapandi and H. Ortega (2014) ‘Not "women's burden": how washing clothes and grinding corn became issues of social justice and development', Gender $\delta$ Development 22(3): 495-513.

${ }^{10}$ M. Silberschmidt (2001) 'Disempowerment of Men in Rural and Urban East Africa: Implications for Male Identity and Sexual Behavior'. World Development 29(4): 657-671.

${ }^{11}$ Oxfam (2017) Women's Economic Empowerment and Care (WE-Care): An Overview. Oxford: Oxfam GB, p.2.

12 T. Kidder and C. Pionetti (2013), revised by U. Chipfupa, J. Remme and T. Kidder (2016) Participatory Methodology: Rapid Care Analysis. Guidance for Managers and Facilitators. Oxford: Oxfam GB.

${ }^{13}$ In Zimbabwe, these focused on districts of Bubi, Umzingwane and Zvishavane.

${ }^{14} \mathrm{http}$ ://www.chronicle.co.zw/starvation-amidst-abuandance-in-bubi/

15 Marcus and Harper (2015) op. cit.

${ }^{16}$ In most areas, Thursday is traditionally a non-working day; no work is done in the fields or no heavy work takes place at all at the behest of the traditional leaders such as chiefs. Thus, if new norms are emerging that see men involved in care work, traditional leaders could be persuaded to declare a day in which men are expected to go fetch water, for instance, as the Chief would see this as necessary and a good norm to bring harmony to families and communities. A public declaration leads to the social expectation that men will carry out this local edict. Such an approach has been used successfully in some communities where Chiefs have declared gender-based violence unacceptable, as spouse-beating is not in keeping with good traditional values.

${ }^{17}$ Note that this saying and the preceding one have the same figurative translation in English. 


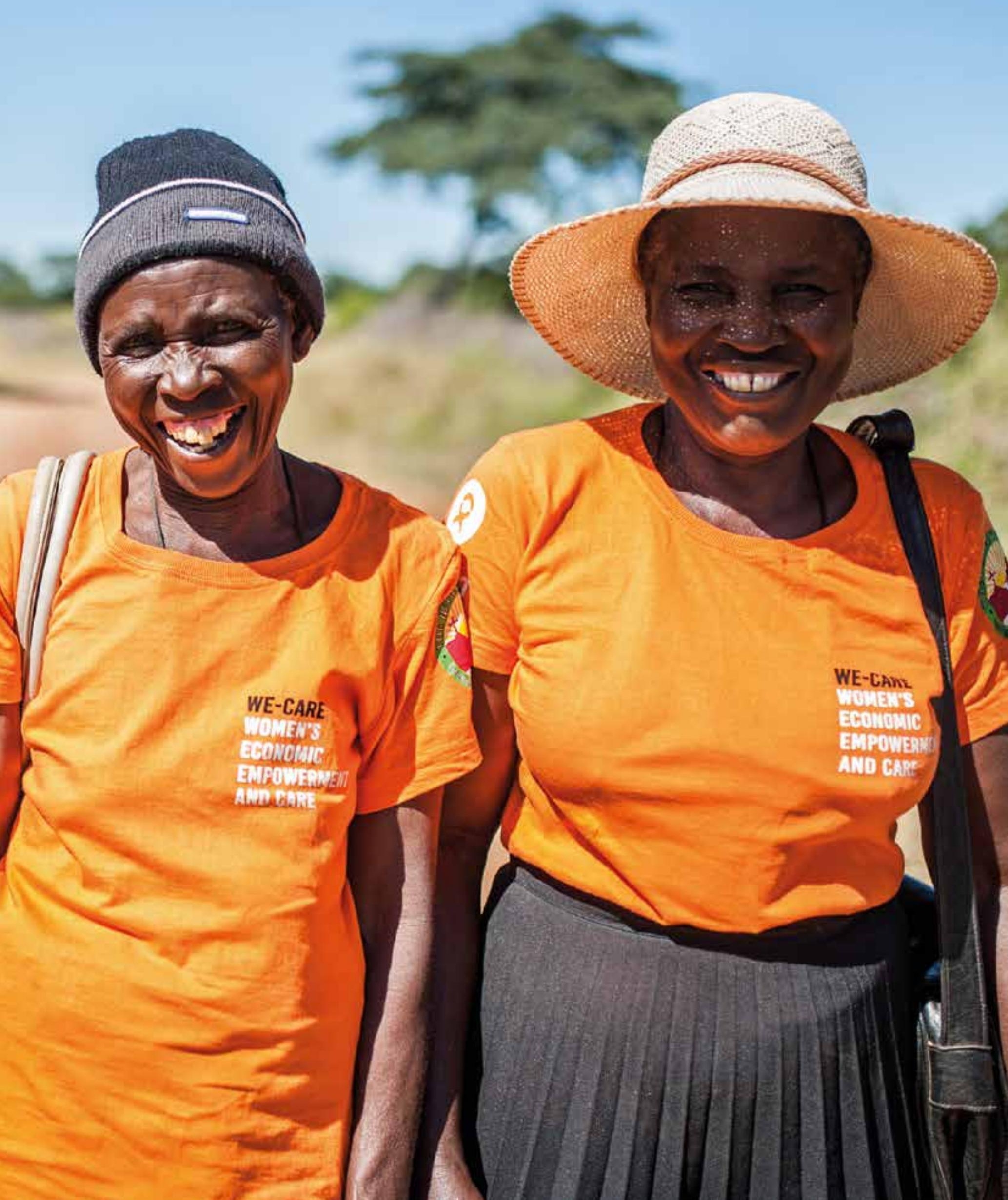




\section{OXFAM REPORTS}

Oxfam reports are written to share results, to contribute to public debate and to invite feedback on development and humanitarian policy and practice. They do not necessarily reflect Oxfam policy positions. The views expressed are those of the author and not necessarily those of Oxfam. This publication was written by Emma Samman with contributions from Imogen Davies, Nomthandazo Jones, Thalia Kidder, Regis Mtutu and Jane Remme

() Oxfam International June 2018

This publication is copyright but the text may be used free of charge for the purposes of advocacy, campaigning, education and research, provided that the source is acknowledged in full. The copyright holder requests that all such use be registered with them for impact assessment purposes. For copying in any other circumstances, or for re-use in other publications or for translation or adaptation, permission must be secured and a fee may be charged.

Email policyandpractice@oxfam.org.uk

The information in this publication is correct at the time of going to press. Published by Oxfam GB for Oxfam International under ISBN: 978-1-78748-221-0 in June 2018

\section{DOI: $10.21201 / 2017.2210$}

Oxfam GB. Oxfam House, John Smith Drive, Cowley, Oxford 0X4 2JY, UK

\section{PHOTOS}

Front cover: Ulita Mutambo and her husband work together to collect water from an Oxfam-built water pump near their home in Ture Village, Zvishavane region, Zimbabwe.

Photo: Aurelie Marrier d'Unienville/Oxfam

Page 7: Melody Mutsauki stands outside her home in the Masvingo region of Zimbabwe with her husband and four children. She also takes care of their cousin who lives with them. Photo: Aurelie Marrier d'Unienville

Page 23: Muchineripi and his daughter Sandra stand outside their home in Ture Village, Zvishavane region, Zimbabwe.

Photo: Aurelie Marrier d'Unienville

Page 35: WE-Care champions stand in Ture Village,Zvishavane region, Zimbabwe. Photo: Aurelie Marrier d'Unienville

\section{ACKNOWLEDGEMENTS}

With thanks to our partners, Unilever, its laundry brand Surf and the William and Flora Hewlett Foundation, for supporting the WE-Care programme.

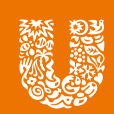

Unilever
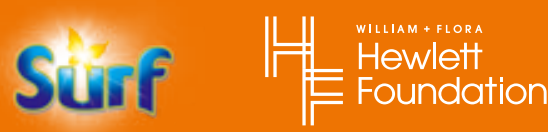

OXFAM

Oxfam is an international confederation of 20 organizations networked together in more than 90 countries as part of a global movement for change to build a future free from the injustice of poverty. Please write to any of the agencies for further information. or visit www.oxfam.org

Oxfam America (www.oxfamamerica.org)

Oxfam Australia (www.oxfam.org.au)

Oxfam-in-Belgium (www.oxfamsol.be)

Oxfam Brasil (www.oxfam.org.br)

Oxfam Canada (www.oxfam.ca)

Oxfam France (www.oxfamfrance.org)

Oxfam Germany (www.oxfam.de)

Oxfam GB (www.oxfam.org.uk)

Oxfam Hong Kong (www.oxfam.org.hk)

Oxfam IBIS (Denmark) (http://oxfamibis.dk)

Oxfam India (www.oxfamindia.org)

Oxfam Intermón (Spain) (www.oxfamintermon.org)

Oxfam Ireland (www.oxfamireland.org)

Oxfam Italy (www.oxfamitalia.org)

Oxfam Japan (www.oxfam.jp)

Oxfam Mexico (www.oxfammexico.org)

Oxfam New Zealand (www.oxfam.org.nz)

Oxfam Novib (Netherlands) (www.oxfamnovib.nl)

Oxfam Québec (www.oxfam.qc.ca)

Oxfam South Africa (www.oxfam.org.za)

\section{WE-CARE \\ WOMEN'S \\ ECONOMIC \\ EMPOWERMENT

